Illinois State University

ISU ReD: Research and eData

Theses and Dissertations

$4-5-2018$

\title{
A Cross-Cultural Comparison Of Perceptions By Public Relations Practitioners In The United States And Germany
}

Leila Schmidt

Illinois State University, leila.ruegen@googlemail.com

Follow this and additional works at: https://ir.library.illinoisstate.edu/etd

Part of the Communication Commons

\section{Recommended Citation}

Schmidt, Leila, "A Cross-Cultural Comparison Of Perceptions By Public Relations Practitioners In The United States And Germany" (2018). Theses and Dissertations. 885.

https://ir.library.illinoisstate.edu/etd/885

This Thesis is brought to you for free and open access by ISU ReD: Research and eData. It has been accepted for inclusion in Theses and Dissertations by an authorized administrator of ISU ReD: Research and eData. For more information, please contact ISUReD@ilstu.edu. 


\section{A CROSS-CULTURAL COMPARISON OF PERCEPTIONS BY PUBLIC RELATIONS PRACTITIONERS IN THE UNITED STATES AND GERMANY}

\section{LEILA SCHMIDT}

\section{Pages}

In our globalized world, becoming aware of the interdependence between public relations and culture becomes more and more important. This cross-cultural study combines an emic and etic approach to explore how PR practitioners in two individualistic countries, the United States of America and Germany, experience and perceive the impact of culture on their practice, specifically the development of campaigns. To understand the broader image, the study incorporates Hofstede's (2009) cultural dimensions; to examine similarities and differences in terms of cultural nuances, the study relates to Spitzberg's (2015) intercultural communication competence. The participants consisted of sixteen male and female PR practitioners working for corporate, agency, and non-profit organizations, with eight respondents from each of the two countries. Results from qualitative one-on-one in-depth interviews reveal that participants in both countries perceive that the organizational culture of the companies that they are working for affect the PR practice, specifically the development of campaigns, more than national cultural values. The results from United States participants, in terms of Hofstede's cultural dimensions, align more than those of Germans with higher masculinity, more uncertainty avoidance, and less long-term orientation, which contradicts extant research. All participants agreed on digitalization and social media being the most influential elements on the development of campaigns, with these simultaneously being beneficial and introducing the challenges of globalization. All of the 
American and only a few of the German respondents showed motivation for becoming more interculturally competent. The findings demonstrate the need for more cross-cultural education and training in both countries.

KEYWORDS: Globalization; Multiculturalism; Public Relations; Culture; Germany; United States; PR practice; Campaign Development; Cross-cultural Comparison; Cultural Dimensions; Intercultural Communication Competence; Emic; Etic 


\title{
A CROSS-CULTURAL COMPARISON OF PERCEPTIONS BY PUBLIC RELATIONS PRACTITIONERS IN THE UNITED STATES AND GERMANY
}

\author{
LEILA SCHMIDT
}

\author{
A Thesis Submitted in Partial \\ Fulfillment of the Requirements \\ for the Degree of \\ MASTER OF SCIENCE \\ School of Communication \\ ILLINOIS STATE UNIVERSITY
}


(C) 2018 Leila Schmidt 


\title{
A CROSS-CULTURAL COMPARISON OF PERCEPTIONS BY PUBLIC RELATIONS PRACTITIONERS IN THE UNITED STATES AND GERMANY
}

\author{
LEILA SCHMIDT
}

COMMITTEE MEMBERS:

John R. Baldwin, Chair

Rebecca Hayes

Phillip Chidester 


\section{ACKNOWLEDGMENTS}

It was a journey with its ups and downs, but a journey that made me learn a lot—not just about the interdependence of public relations and culture, but about myself, and about the importance of having people behind me who will never let me down.

I realized that I would not have been able to end this journey successfully without the strong support system behind me. First of all, I would like to thank my chair, Dr. John Baldwin, who I see as an intercultural communication genius. He taught me so much that I was able to apply not only in theory for my thesis but also in real-life interactions. He always made time to help me out and gave me useful advice. I also want to thank Dr. Rebecca Hayes for her support with the PR-specific part of my thesis. I am grateful that I was always able to show up in her office and ask for her inspiring input and expertise. Last, but not least, I am grateful that Dr. Phil Chidester was on my committee since he came up with great ideas that I had not even taken into consideration before; it was always a pleasure to talk about our intercultural experiences in other countries.

Besides the wonderful academic support that I received, I would also like to thank my amazing family for always being there for me. Without them, I would not be who and where I am today. They made all my study abroad experiences possible and never stopped me from any of my international adventures. They always encouraged and believed in me, which made me become a lot stronger.

Thank you to everyone who kept on motivating me. I am proud of my achievements and am looking forward to ending this journey and starting a new one. 


\section{CONTENTS}

Page

ACKNOWLEDGMENTS

$\begin{array}{ll}\text { CONTENTS } & \text { ii }\end{array}$

CHAPTER I: INTRODUCTION 1

CHAPTER II: LITERATURE REVIEW 3

Globalization and Its Effects on Culture and Public Relations 3

Public Relations Definitions and Types $\quad 4$

Types of PR $\quad 5$

$\begin{array}{ll}\text { Corporate } & 6\end{array}$

$\begin{array}{ll}\text { Agencies } & 6\end{array}$

$\begin{array}{ll}\text { Non-Profit Organizations } & 7\end{array}$

$\begin{array}{ll}\text { The Development of Campaigns } & 7\end{array}$

$\begin{array}{ll}\text { ROSTE Model } & 8\end{array}$

International Application $\quad 9$

The Interdependence between Culture and Public Relations 10

Organizational Culture $\quad 11$

Hofstede's Cultural Dimensions $\quad 12$

$\begin{array}{ll}\text { Power Distance } & 12\end{array}$

$\begin{array}{lr}\text { Individualism vs. Collectivism } & 12\end{array}$

Masculinity vs. Femininity 13

$\begin{array}{ll}\text { Uncertainty Avoidance } & 13\end{array}$

Long-term vs. short-term orientation $\quad 13$ 
$\begin{array}{ll}\text { Indulgence versus restraint } & 14\end{array}$

Application and Critique of Hofstede's Cultural Dimensions $\quad 14$

Cultural Similarities and Differences between Germany and the United States $\quad 16$

Public Relations Development in the United States 18

$\begin{array}{ll}\text { Public Relations Development in Germany } & 19\end{array}$

$\begin{array}{ll}\text { Multiculturalism } & 20\end{array}$

PR Practitioners in a Multicultural Environment 22

Theoretical Framework: Intercultural Communication Competence 23

$\begin{array}{ll}\text { Rationale and Research Questions } & 26\end{array}$

$\begin{array}{ll}\text { Conclusion } & 28\end{array}$

$\begin{array}{ll}\text { CHAPTER III: METHODS } & 29\end{array}$

$\begin{array}{lr}\text { Participants } & 29\end{array}$

$\begin{array}{ll}\text { Data Collection } & 30\end{array}$

$\begin{array}{ll}\text { Procedure } & 31\end{array}$

$\begin{array}{ll}\text { Interview Protocol } & 32\end{array}$

$\begin{array}{ll}\text { Data Analysis } & 32\end{array}$

Coding, Unitizing, and Categorizing 32

$\begin{array}{ll}\text { Establishing Credibility } & 34\end{array}$

$\begin{array}{ll}\text { Conclusion } & 34\end{array}$

CHAPTER IV: RESULTS 36

Definition and Perception of Public Relations 36

$\begin{array}{ll}\text { Role of Culture in PR } & 37\end{array}$

$\begin{array}{ll}\text { National Focus } & 37\end{array}$ 
$\begin{array}{ll}\text { Cultural Values } & 39\end{array}$

$\begin{array}{ll}\text { Company Culture } & 40\end{array}$

The Impact of Multicultural Experiences $\quad 41$

$\begin{array}{ll}\text { Cultural Dimensions } & 42\end{array}$

$\begin{array}{ll}\text { Masculinity } & 42\end{array}$

Uncertainty Avoidance $\quad 43$

Long-term orientation $\quad 44$

Development of Intercultural Communication Competence 45

$\begin{array}{ll}\text { Effectiveness } & 45\end{array}$

$\begin{array}{ll}\text { Appropriateness } & 46\end{array}$

$\begin{array}{ll}\text { Knowledge } & 48\end{array}$

$\begin{array}{ll}\text { Motivation } & 48\end{array}$

$\begin{array}{lr}\text { Skills } & 50\end{array}$

Challenges and Benefits of Multiculturalism and Globalization for PR Practice $\quad 51$

Social Media and Digitalization $\quad 51$

International Audiences $\quad 52$

$\begin{array}{ll}\text { Challenges } & 53\end{array}$

$\begin{array}{ll}\text { Benefits } & 54\end{array}$

$\begin{array}{ll}\text { Conclusion } & 54\end{array}$

CHAPTER V: DISCUSSION

Summary of Findings $\quad 56$

$\begin{array}{ll}\text { Theoretical Framework } & 58\end{array}$

$\begin{array}{ll}\text { Practical Implications } & 60\end{array}$ 
Strengths and Limitations

Future Research

Conclusion

REFERENCES 


\section{CHAPTER I: INTRODUCTION}

"Public relations has gone global." This statement made by scholars Bardhan and Weaver (2011, p.1) perfectly describes the change this field has gone through and demonstrates how important it is to connect public relations scholarship with Intercultural Communication research. As our world is becoming more and more globalized, the need of conducting cross-cultural and comparative studies is growing in order to make people aware of benefits and challenges. Multiple scholars (Huang, 2011; Rebeil, Corella \& Herrera, 2011; Sriramesh, 2009) emphasize the unavoidability and criticize the lack of research in this understudied field.

Although public relations scholars have taken the development of international public relations into consideration in the past, most of the former research focuses on the differences that occur in public relations (PR) practice and application (e.g., Jain, De Moya, \& Molleda, 2014; Lee, 2004; Taylor, 2000). Public relations scholarship, however, rarely examines the experience and cultural awareness of PR practitioners themselves and how cultural dimensions affect the development of campaigns. Besides that, a content analysis by Jain, De Moya, and Molleda (2014) revealed that most cross-cultural comparisons only explore the differences and similarities between western and eastern countries, often using Hofstede's (1984, 2001) cultural dimensions, such as individualism and collectivism. There is a lack of cross-cultural studies that take countries with similar cultural backgrounds into consideration. However, national culture similarities do not necessary apply to all fields. They only help in getting a broad, general understanding of national cultural values from the outside, the etic perspective, which has been criticized by several scholars (e.g., Courtright, Wolfe, \& Baldwin, 2011). There is a need for more emic research that focuses on the cultural specificities, which this study contributes to by combining an etic and emic approach. 
Moreover, previous research has not explored the impact of cultural variables on PR practitioners' education and practice in terms of developing campaigns in multicultural settings, although newer articles (e.g., Sison, 2009; 2017; Yeo \& Pang, 2017) emphasize how having communities that consist of people with different cultural backgrounds who live and work together are a new challenge in the PR practice that must be addressed.

These findings led me to my interest in conducting a cross-cultural study of the development of campaigns between PR practitioners in Germany and the United States, two individualistic countries with similar national values and cultural dimensions that both experience increasing immigration numbers, which result in the emergence of multiculturalism. I designed this study to contribute to the research that focuses on the interdependence of public relations and culture. Hence, this study makes use of Hofstede's $(2001,2009)$ cultural dimensions to compare the broader outside view; the components of Spitzberg's (2015) intercultural communication competence model - motivation, knowledge, and skills - will guide the exploration of particular cultural nuances.

I will first review literature to provide a better understanding of the terms that have a huge impact on this study, namely globalization, culture, and public relations, and explain differences and similarities between the United States and Germany. An analysis of interviews with German and American PR practitioners will then explore the perceived interdependence between culture and public relations, and its impact on the development of campaigns in both countries. 


\section{CHAPTER II: LITERATURE REVIEW}

In order to get a better understanding of how globalization, public relations, and culture are connected to each other, in the first section of this chapter, I will explain the meanings and development of these terms, followed by providing a deeper insight of cultural dimensions with a specific focus on similarities and differences between the United States and Germany. The last section consists of the exploration of multiculturalism and its impact on PR practitioners' work and explains what role the development of intercultural communication competence plays.

\section{Globalization and Its Effects on Culture and Public Relations}

To begin with, it is important to understand what the terms globalization, culture, and public relations represent, and how these things affect each other. Globalization is a complex term that refers to a variety of disciplines and phenomena (Bardhan \& Weaver, 2011). Scholars have provided a variety of definitions of globalization, some seeing it in terms of movement and migration, international media, transnational technology and financial development (Appadurai, 1996), and others in terms of deeper questions that relate to history, philosophy, and epistemology (Applebaum \& Robinson, 2005).

Scholars also debate the effects of globalization. Some tend to look at its economic impact on and its interdependence with multinational corporations (Friedman, 2005); others take a more critical stance and focus on inequality in terms of power divisions among cultures (Held \& McGrew, 2000) or examine the transformational perspective in terms of new possibilities and changing ideologies (Martell, 2007). What they all have in common is that they see globalization in terms of the result of "compression of time and space" (Bardhan \& Weaver, 2011, p. 5).

Globalization has great influence on societies and their communication, specifically, public relations. Globalization has not only changed the business and the development of 
interpersonal relationships, but also calls for a new definition of terms like culture, which will be defined later in this chapter Communication studies and the field of public relations have been part of this global development. To get a better understanding, PR scholarship started to focus more on the conceptualization of interdependence and interconnection as well as power relations and cultural dimensions (Bardhan \& Weaver, 2011). Reaching out to the publics through PR started out as a Western concept. Over the past few decades, this approach became more and more popular among practitioners in various countries, cultures and societies, with slight differences in the perception and application of PR. As Debeljak (2011) states, "Modernization and westernization of individual societies are Siamese twins" (p. 49).

\section{Public Relations Definitions and Types}

It is important to differentiate between the origins of public relations and the term itself. Whereas PR, as it is known and applied in the United States, was first practiced in Germany, the term itself was manifested in the United States (Parkinson \& Ekachi, 2006). According to the most updated definition by the Public Relations Society of America (2012), "Public relations is a strategic communication process that builds mutually beneficial relationships between organizations and their publics," which is a statement that many scholars agree on (e.g., Bardhan \& Weaver, 2011; Sriramesh, 2009; Sriramesh \& Vercic, 2009).

As Miller and Dinan (2003) point out, public relations went hand in hand with capitalism and spread more and more worldwide during the last decades of the 20th century. What started out as help for US agencies became a global concept to connect a variety of entities with the public. Until today, US public relations models and concepts are the ones that are mainly found in textbooks and taught at universities (McKie \& Munshi, 2007; Sriramesh, 2004). However, articles written by scholars from different countries show that not all countries and cultures are 
aligned with the practice of PR as it is known in the United States (e.g., Sriramesh \& Kim, 1999; Vercic, van Ruler, Buetschi, \& Flodin, 2001). The same applies to the education and training of PR practitioners. Vercic et al. (2001) conducted a research project with respondents from a variety of European countries over three years, which revealed that "linguistic and cultural idiosyncrasies has direct relevance for the definition, dimensions, and domain of public relations" (p. 377). The scholars emphasize that the results of their study identified difficulties with the universal use of the US definition and approach to public relations. They, furthermore, raised awareness of the need to address these differences through the adding of international perspectives. As Sriramesh (2002) found out in a study that explored three Asian countries' perspectives of PR education, even the few books that focus on international public relations mainly refer to American PR concepts and norms. In order to avoid a "west-centric" approach to public relations (Bardhan \& Weaver, 2011, p. 7), scholars like Curtin and Gaither (2007) call for the development of PR models that take the change caused by globalization into consideration; leading to an interplay of and blurred lines between identities and cultural dimensions.

Not only does the definition and application of public relations vary among countries, different organizations also adjust their approach to and practice of PR to their culture and purpose. In order to understand what practitioners in each field particularly have to pay attention to, it is important to distinguish the PR practice between corporate agencies, and nonprofit organizations.

\section{Types of PR}

Although scholars usually use the term public relations to refer to the management and maintenance of relationships between an organization and its publics (Grunig \& Hunt, 1984), the various types of PR entities are characterized by the differences in their cultures, practitioners, 
and styles when developing PR campaigns. Croft (1999) points out the biggest difference between corporate and agency PR: while corporate is the "inside looking out," with organizations promoting their own interests, services or products, agencies are "the outside looking in" (p. 96), serving clients.

Corporate. Corporate public relations operations are aligned with the values of their corporation as well as the ones of the nation where the company is based out of (Olasky, 2013; Vercic, 2011). Their main function consists of addressing multiple publics through different media and at various paces, depending on the event and situation, which makes it important for them to build rapport and maintain relationships with a variety of stakeholders (Olasky, 2013). One of the main skills for PR practitioners to have is the adjustment of their communication style to the variety of industries that they might have to work with during one day as well as the ability to compartmentalize the time since it is a very fast-paced environment (Kim \& Reber, 2008). Start-ups can be seen as a smaller version of corporate companies; their public relations practice follows the same pattern, just on a smaller scale since they are still growing and working on the development of their departments (Gregory, 2000).

Agencies. Vercic (2011) describes the culture of a PR agency as a "publicist, journalistic culture, largely influenced by the previous socialization of their personnel in media organizations" (p. 243). The systems tend to be looser, characterized by an informal style that makes it possible for practitioners to adjust their communication style to the corresponding media type. The development of stories requires great writing and editing skills from agency practitioners since they tend to focus on crises or opportunities to bring their word out to the mass media (Vercic); thus, publicity is the key word to describe the agency PR culture. 
Non-Profit Organizations. The problem with non-profit organizations is the lack of a clear definition, as Froehlich and Peters (2015) point out, since there are many different types

that have different intentions in the political, sociocultural, and charitable field. The purpose of non-profit organizations, however, is similar to that of corporates: They communicate in behalf of their own company. What differentiates them is the primary goal for their PR. Whereas corporates aim to make profit, nonprofits "seek to win public support of their mission and programs through active and open communication" (Seitel, 2007, p. 256). Regardless of the area in which PR practitioners work, they all have to follow an effective system when developing campaigns, which consists of messages sent out by an entity to their target audience publics that are utilized to spread the word of an important piece of news, which can have the goal either to promote or defend ideas, products, or behaviors, depending on the situation (Sheehan \& Xavier, 2009).

\section{The Development of Campaigns}

According to Barnard and Parker (2012), a campaign is "a planned sequence of communication that makes use of all appropriate channels to achieve defined outcomes in a specific timeframe by influencing the decision-makers who will allow success" (p. 9). The development of a campaign is a time-consuming process, starting with a clear statement of a goal and specific objectives that will decide which strategies and tactics to use in order to be appropriate and effective (Austin \& Pinkleton, 2015). There are different models that scholars use to explain the parts and steps of creating public relations campaigns; they all have different acronyms, for example ROSTE (Parkinson \& Ekachai, 2006), RACE (Marston, 1963), or ROPE (Hendrix, 1998), but focus on the same steps, so I will explain on the basis of the ROSTE Model. 
ROSTE Model. An internationally recognized model that scholars use to explain the parts and steps of creating a public relations campaign is called ROSTE, which stands for Research, Objectives, Strategies, Tactics, and Evaluation (Parkinson \& Ekachai, 2006). To provide a better understanding of the importance of the inclusion of each of these components and the necessity to manage them effectively, I will explain them in more detail:

The first part of the model, research, focuses on questions like: What media sources are available? What are the cultural norms? In other words, the model takes into consideration not only what has been done successfully so far, but also what changes practitioners have to take into consideration and how they can adjust campaigns in order to achieve an appropriate application that ensures a positive perception by target audiences (Marston, 1963). When talking about objectives, Hendrix (1998) emphasizes that these can either focus on impact in terms of informing and influencing attitude, or on output, which refers to the appropriate execution. In summary, the second phase consists of having measurable and defined time frames combined with providing valuable work.

The third step, strategies, focuses on the "selection of messages [that] must be based on an understanding of culture of the target public" (Parkinson \& Ekachi, 2006, p. 91). This phase refers to the use of sensitivity and awareness as part of actions that the PR professionals have to undertake. An example would be the choice of an appropriate spokesperson. Whereas strategies refer to plans and actions, tactics describe the use of tools, for example, the directedness of the communication style and the choice of the most effective medium, depending on the cultural environment. To the end, PR professionals evaluate the campaign's effectiveness and success. They can measure the change through the satisfaction of clients and the target audience (Parkinson \& Ekachi, 2006, p. 91). 
International Application. The ROSTE model can be used as framework in various countries and cultures, be it when talking about objectives or coming up with effective strategies; PR practitioners can easily adjust details internally, depending on the organization's needs. No matter whether this model is applied for a national or global campaign, it is important to consider the different cultural backgrounds of the practitioners and stakeholders, thus to be aware of its "constant evaluation and modification" (Parkinson \& Ekachai, 2006, p. 90) that play a significant role in providing reliability and validity for its application. As pointed out by Gudykunst (2005), tolerance, patience, and mindfulness are important intercultural communication skills that can be helpful during the development of campaigns. An example that demonstrates how not being inclusive and aware of various cultural implications can make a company's reputation suffer, is a recent campaign by Pepsi. It received a lot of criticism for borrowing elements from the Black Lives Matter movement with a White model being part of the protest and representing the brand (e.g., Victor, 2017). Sensitivity and the openness for changes and adjustments have to be part of the campaign development in order to work inclusively (Parkinson \& Ekachai, 2006). The consideration of goals, cultures, and capabilities in relation with what is realistic and what can be accomplished brings along more limitations, but less exclusion and failures of campaigns.

Many scholars (e.g., Hon \& Brunner, 2000; Oliveira, 2013; Shome, 2012) refer to a broader set of issues in PR campaigns that are delivered in more than one country, or that try to address multiple target audiences with different cultural backgrounds within one country. An example that Oliveira (2013) points out is the "lack of cultural sensitivity" (p. 257) that can lead to misunderstandings, which can cause a message to be ineffective or even inappropriate.

Today, this cultural variety is becoming more of a priority because of a drastic change in the work and private setting, impacted by the increasing numbers of immigrants in the United 
States and Germany (Statistisches Bundesamt, 2018; U.S. Census Bureau, 2016). As becomes clear, the surrounding culture affects the application of public relations as well as its role in the society.

\section{The Interdependence between Culture and Public Relations}

"Culture is communication and communication is culture" (Hall, 1959, p. 97). This statement by scholar Edward Hall best describes the interdependence between these two phenomena; by extension, it shows that culture influences PR when practiced across borders but also within the same nation, or even the same organization, since every person is coined by different backgrounds, values, and beliefs, which are key components of culture (Hall, 1976; Kim, 2001). Since Public Relations is fundamentally about the establishment and development of relationships, and culture has an impact on all types of human communication (Sriramesh, 2012), it is important to see the connection between these concepts.

Culture influences people's behavior, as well as their norms and rules, since they experience it subconsciously through the process of socialization (Hall, 1976; Kim, 2001). Globalization changes the conceptualization of culture and territory from being synonymous (Clifford, 1997) to being hybrid (e.g., Bardhan and Weaver, 2011). Sriramesh (2012) expands the notion of culture beyond societal elements to include political economy, media, and activist culture when considering the interdependence between Public Relations and culture. Sriramesh and Vercic (2009) expand on Grunig's and Hunt's (1984) definition of public relations, cited earlier, by adding a cultural element to it. They refer to it as "the strategic communication that different types of organizations use for establishing and maintaining symbiotic relationships with relevant publics, many of whom are increasingly becoming culturally diverse" (Sriramesh \& Vercic, 2009, p. 34). 


\section{Organizational Culture}

An important aspect to take into consideration as part of the analysis of the interdependent relationship between PR and culture is the factor that public relations itself can be referred to as a culture with a main focus on its people, its practitioners. Organizational culture refers to an organization's identity, that is, who they are and what they stand for, often referred to as their vision and mission statements (Schultz, Hatch, \& Holten Larsen, 2000). This identification takes place not only externally but also internally, so that members can portray the experienced and perceived everyday organizational life beliefs and values when communicating with the publics (Geertz, 1973; Hofstede 1980). Often, people say that "the social role of public relations - and thereby its identity - is a work in progress" (Sriramesh, 2012, p. 20). Scholars agree that campaigns have to be adjusted to multiple cultures in order to be successful (Parkinson

\& Ekachai, 2006; Sriramesh \& Vercic, 2003); that means that a mutual understanding of a shared culture should be the case between "the client, public relations practitioner, and the target public" (Parkinson \& Ekachai, 2006, p. 66).

In order to better understand the role of culture in communication, scholars have tended to take either an etic approach, which uses terms and frameworks developed by scholars to compare multiple cultures, or emic approaches, which seek understanding of cultural ways from within the culture (Gudykunst \& Nishida, 1989). An example for an etic approach is Lewis' (2006) model that compares cross-cultural differences among countries on three dimensions: linear-active (cool, factual, decisive planners), multi-active (warm, emotional, loquacious, impulsive), and reactive (courteous, amiable, accommodating, compromisers, good listeners). 


\section{Hofstede's Cultural Dimensions}

Cultural researchers have provided different ways of understanding and explaining the similarities and differences between countries with various cultural backgrounds, including dimensions as a basis for comparisons (an etic approach). One such approach that has received much attention by cross-cultural PR scholars is Hofstede's dimensions (Courtright, Wolfe, \& Baldwin, 2011). Geert Hofstede (1984) developed a survey study to compare core values among employees of 50 nations worldwide and identified cultural dimensions. His original publication of scales that referred to the explanation of four dimensions found great appeal among scholars who conducted cross-cultural studies. Critiques from other scholars, as well as newer findings, as will be explained below, led Hofstede (2010) to the addition of two more dimensions.

Power Distance. The first dimension refers to power distance, which explains how important the status and roles among members of the same culture are within cultural groups, and what impact they have on the conduct toward each other. An example that Sriramesh and Kim (2000) used to visualize this dimension is the Indian caste system, which reflects high power distance.

Individualism vs. Collectivism. Hofstede's (2001) second dimension takes into consideration whether a nation is more individualistic or collectivist, which depends on whether the individuals within one culture or important ingroups are valued more than outgroups (Hofstede, 2001). Various scholars who conducted cross-cultural studies (e.g., Gudykunst, Yoon, Nishida, 1987) found that members of individualistic cultures experience less difficulty talking to and criticizing strangers than members of collectivist cultures. Closely connected to Hofstede's second dimension is Hall's (1976) explanation of low-and high-context 
communication patterns. Members of individualistic groups tend to be more direct and explicit in their statements, whereas people in collectivist cultures prefer the use of implicit language.

Masculinity vs. Femininity. Hofstede's (1984) third dimension refers to the role that masculinity and femininity play in a cultural society, which relates to certain expectations and behaviors that are "more suitable to females or more suitable to men" (p. 177). Societies that focus on competition and rewards reflect masculinity, whereas feminine cultures prefer consensus and cooperation. Further, masculine cultures tend to favor role rigidity, with distinct social roles for males and females, and feminine cultures have more role fluidity, or overlap between what men and women do.

Uncertainty Avoidance. The fourth category, which Hofstede (1984) labels uncertainty avoidance, refers to the likeliness of cultural members to accept ambiguity and unpredictability. There, again, is a close connection between this dimension and Hall's (1976) notion of high- and low-context communication. High-context communicators tend to have a higher tolerance level for ambiguity than low-context ones. Uncertainty avoidance also relates to people's likeliness to take risks. If a culture is characterized by low uncertainty avoidance, the members of that group acknowledge and tolerate the ambiguity of existence, which leads to a higher engagement in risk-taking and less predictions and fears about the future.

Long-term vs. short-term orientation. The fifth dimension that Hofstede (2009) added more recently, focuses on long-term orientation, that is, a culture's attitude towards change. This dimension explains how beliefs among cultural groups influence decisions. Hofstede differentiates between societies convinced of the created moral and will in the world as it is and those that support transformations and preparedness for coming changes in the future, such as through discipline, education, and hard work. Societies with a short-term approach put traditions 
first, and do not support newer concepts and changes as much as long-term focused societies that prefer a more pragmatic, future-oriented thinking (Hofstede Insights, 2018).

Indulgence versus restraint. Hofstede's (2010) sixth dimension deals with regulations and freedoms. Members of indulgent cultural groups experience "relatively free gratification of basic and natural human drives to enjoying life and having fun" (Hofstede Insights, 2018). In contrast to indulgent societies, restraint ones allow for less enjoyment and focus on the strict following of regulations and norms that leads to a following the social prescriptions that duty requires of different roles (e.g., supervisor-employee) at all times.

\section{Application and Critique of Hofstede's Cultural Dimensions}

Hofstede developed scales to sort countries according to these cultural dimensions and applies the dimensions to the general behavior and communication style of inhabitants of those nations. Many scholars who connect culture and public relations in cross-cultural studies make use of Hofstede's $(1984,2001)$ cultural dimensions when explaining similarities and differences in terms of power, communication behavior, and outcomes (e.g., Kim \& Kim, 2009, 2010; Rhee, 2002). Specifically, Hofstede's power distance dimension has been identified as an important factor when explaining the difference in its practice (Jiang \& Wei, 2013; Mustasha \& De Troyer, 2009; Sriramesh \& White, 1992). Taylor and Kent (1999) found that countries with low power distance, like the United States, tend to reach out to multiple target audiences at the same time since they value equality and authoritarianism less. Huck (2004) explored how Hofstede's (2001) cultural dimensions had an impact on PR in Germany and confirmed the collective-individual dichotomy. She found that the national culture of the practitioner was more influential for the development of campaigns than the corporate culture. 
Although these dimensions provide basic explanations for the interdependence between public relations and culture that have often been applied as a tool in cross-cultural studies to explain the PR practitioners' approach to the audience, they also experienced a lot of criticism in its methodology, application, and conceptualization. Courtright, Wolfe, and Baldwin (2011) summarized multiple critique points made by various scholars and emphasized the need for alternatives that are less static and not focused only on national borders. As several scholars point out (e.g., Baldwin, 2018; Casmir, 1999; Collier, 1994; Ting-Toomey, 2012), culture is not necessarily bound to national borders. Methodologically speaking, the creation of Hofstede's $(1984,2001)$ scale items and dimensions experience criticism because of possible issues related to translation misunderstandings and the possibility that the samples might not be generalizable to the culture of an entire nation (Cai, 1998; McSweeney, 2002).

Besides that, Hofstede's dimensions only take an etic approach, which is Li's (2012) point of criticism in her discussion of advantages and disadvantages between emic and etic approaches to cross-cultural studies. Since Hofstede developed dimensions in order to compare elements of the nations' cultures, the dimensions provide an etic framework, namely the development of universal, external categories that result in the "drop[ping of] the unique parts of each culture" (p. 111). Some cultural peculiarities can be compared through this approach, but the different cultural and behavioral specifications should also be explored through an emic approach, which refers to understanding a culture from a view internal to the culture (Davidson, Jaccard, Triandis, Morales, \& Diaz-Guerrero, 1976; Morris, Leung, Ames, \& Lickel, 1999; Pike, 1966). In order to get results that simultaneously focus on culture-specific aspects and allow for a comparison of both countries and their cultures, several researchers recommend the combination 
of emic and etic approaches (e.g., Baldwin et al., 2014; Berry, 1990; Davidson et al., 1976; Morris et al., 1999).

For effective intercultural and cultural public relations, it is important to have "empirical evidence on the nexus between the specific cultural idiosyncrasies of individual countries and PR practice before it is possible to globalize some of the cultural principles" (Sriramesh, 2002, p. 63). In sum, it can be useful to do a specific comparison of similarities and differences between countries when doing cross-cultural comparisons that not only makes use of Hofstede's dimensions or other universal models, but also takes the individual internal cultural sides into consideration Hence, for the purpose of this study, the next section will analyze cultural similarities and differences between the United States and Germany on both levels.

\section{Cultural Similarities and Differences between Germany and the United States}

A comparison between Germany and the United States makes clear that they are aligned in terms of sharing cultural values, standards, and norms. A consideration of Hofstede's (2001) dimensions and Lewis' (2006) model show that the United States and Germany are very similar, culturally speaking. Both countries fall into the linear-active category (Lewis, 2006) and are referred to as individualistic and direct (Hall, 1976; Hofstede, 2001).

Hofstede (2001) categorized the United States as the most individualistic country in the world, describing Americans as informal and participative communicators with a focus on openness towards new acquaintances and a convenient hierarchy within organizations. Germany is also characterized by an individualistic culture and has the small power-distance system and low-context communication in common with the United States (Hall, 1976; Hofstede, 2001; Oetzel et. al, 2003). However, Germans self-report as being less individualistic than U.S. Americans (Hofstede, 2001), which becomes specifically obvious in encounters with new people 
when Germans tend to be more reserved (Hall \& Hall, 1990; Hinner, 2001). Americans, on the other hand, enjoy small talk and focus on being liked (Friday, 1989). Friday (1989) found that Germans insist in a more thorough and much longer training period for new managers than Americans, which he related to Germans' higher uncertainty management that would result in more effective plans, decisions, and short-term solutions. Although people of both countries have the same approach to time orientation and punctuality, they differ in their attitude towards planning. Germans prefer to keep plans as they are, whereas Americans do not avoid a change of plans as much (Hall \& Hall, 1990).

People in both countries prefer a direct communication style, but differ when discussing disagreements and in the finding of solutions. Whereas Germans prefer to "discuss issues thoroughly and completely" (Oetzel et al., 2003) and do not mind confrontation and bluntness, U.S. Americans tend to have calmer discussions that do not necessarily provide long-term but rather short-term solutions. Business studies (Hall \& Hall, 1990; Hinner, 2001) found that Germans in contrast to Americans avoid small talk, but rather focus on efficient discussions with long-term solutions as the outcome. This rather reserved and serious behavior is often perceived as impolite and distant by Americans (Clackworthy, 1996; Hinner, 2001, Hall \& Hall, 1990).

As noticed above, the cultural values and norms not only have an impact on interpersonal relationships and private discourse between American and Germans, but affect business situations. The same applies to the development of particular forms of communication or the use of media. The United States and Germany approach public relations in a similar way but have experienced shifts and changes at different times because of historical and cultural factors. 


\section{Public Relations Development in the United States}

With the enormous size and population of the United States, its increasing variety in terms of people and their background has always been a challenge in the public relations field (Grunig \& Grunig, 2003). Right after the immigration wave happened following World War II, the need and request for mediators between clients and their publics became bigger and bigger (Grunig \& Grunig). According to Grunig and Grunig, "The field is rooted in less-than-effective and -ethical practice" (p. 337) and did not experience a real development until the 1980s. That decade saw a rapid growth of practitioners. When comparing the 1960s and the 1980s, scholars (e,g., Cutlip, 1995; Grunig \& Grunig, 2003) identify a focus on policies instead of publicity, a growing number of women as practitioners, and a higher accountability because of a breakthrough in research and theory developments as major achievements.

Today, the majority of all US PR practitioners have at least a bachelor's degree when entering the field (Bureau of Labor Statistics, 2018). ) PR practitioners' focus is on strategic planning; they are in charge of various tasks, for example media relations, project management, and crisis management (Cutlip et al., 2000). Bloom (2002) emphasizes how the value and vitality of public relations has grown over time. On the other side, negative associations with the term public relations have also increased (Grunig \& Grunig, 2003), which is why the Public Relations Society of America (PRSA), founded in 1984, emphasizes the importance of ethical codes and accreditation (PRSA, 2018).

Because of the United States' economic situation, which is characterized by capitalism and the impact of big companies, corporate culture is one of the most influencing factors for their public relations (Sriramesh, Grunig, \& Dozier, 1996). As a result, the main work environment 
for PR practitioners consists of multinational companies. This explains the need for the application of more strategic communication.

According to the U.S. Bureau of Labor Statistics (2017), 259,600 people are currently working as PR practitioners all over the United States. Their average pay sits at $\$ 58,020$ per year. As made clear by Gudykunst (2014), the United States culture is becoming more and more pluralistic, which will influence the PR practice tremendously.

\section{Public Relations Development in Germany}

As the country that first made use of the term public relations, Germany has a long history in this field. German scholar Guenter Bentele (1997) named the beginning of the nineteenth century to the end of World War I as the first period of German PR history. Back then, PR was mainly used in the political field. From that point on, it has gone through an immense change because of historical events, from being a tool "to stabilize the system from the top" (Bentele \& Seiffert, 2011, p. 127), a submissive propaganda instrument by Nazis, to its institutionalization as part of a civic culture. German PR adopted many ideas from the US system and experienced "a cultural shift from a mainly national culture to an emerging influence of corporate culture on PR" (p. 127).

However, what makes a difference in the approach and use of PR between Germany and the United States are the different cultural patterns. Whereas innovations in the US focused on best practice, Germany's rationality type was the result of the emphasis on "best principles" (Guenther, 2007, p. 171), which led to what makes up PR in Germany nowadays: the connection to the country's deliberative culture, the connection of it as a reasoning public, and its practice with a focus on "mutual understanding within society" (Bentele \& Seiffert, 2011, p. 131). German PR is in some aspects aligned with Grunig and Hunt's (1984) symmetrical model of PR, 
but rather fits Habermas' (1981) theory of communicative action when considering how it does not only communicate to but with its publics.

Whereas organizational culture is more seen "as a contributing factor to excellence" for the PR practice (Bentele \& Seiffert, 2011, p. 134) in the United States, in Germany it has more relevance in the organization of the PR process and the application itself. Bentele (1997b) added some features to the definition by Grunig and Hunt (1984) that are focused on the inclusion of organizational and societal functions: "monitoring, information, communication, persuasion (primary functions), image building, continuous building of trust, management of conflicts, the building of social consensus" (Bentele, 1997b, p. 22). These add-ons demonstrate the impact of German history and memory on its development and practice. This influence, however, is not one-sided. Not only does German culture have an impact on public relations, PR itself functions as an implementing source of constructing the community in terms of being a guide that serves as a commemorator of its history, organization, and forms the nations' narrative (Assmann, 2007; Sennett, 2007).

Today, more than 40,000 people have officially been identified as public relations practitioners in Germany, the majority of them being women, with more than $90 \%$ having a college degree (Bentele, Seidenglanz, \& Fechner, 2015). The average salary for PR practitioners accounts for $67,000 €$, which equals $\$ 80,000$ (Bentele et al., 2015).

\section{Multiculturalism}

As noticed earlier, due to globalization, a development that both countries have been and are experiencing is an increasing number of immigrants from a variety of countries and variety of cultural backgrounds (Sriramesh \& Vercic, 2003; Statistisches Bundesamt, 2018; U.S. Census Bureau, 2016). 
Whereas former research likes to differentiate between Western and Eastern cultures as individualistic and collectivist ones, newer research does not only take that into consideration, but also the occurrence of multiculturalism, which is rather seen as a concept of having cultural diversity among the population of one country (Sison, 2009). Chen and Starosta (2008) predicted a decade ago that this form "will become the norm rather the expectation in American life" (p. 216). Moosmueller and Schoenhuth (2009) call Germany “an immigration country” (p. 220). In both countries, people with different values, attitudes, and worldviews as well as languages and religious views are living together in the same community; this would be referred to as multiculturalism.

Banks (2000) names migrations, internationalization, a change in trades, and communication technology as the four main factors for growing diversity among nations and a more "international setting" for organizations (p. 9). Often, people tend to associate culture with country boundaries although several cultures can be found within one country, even within one entity, or one family (e.g., Banks, 2000; Ting-Toomey, 2012; Sriramesh \& Vercic, 2003). The key concept for a unit sharing the same culture is the concept of distinctive identification and shared value systems and categories, which can refer to a variety of aspects, for example language, religions, or biological sex. This variety suggests an addition to the original PR definitions: the importance of "taking full account of the normal human variation in the systems of meaning by which groups understand and enact their everyday lives” (Banks, 2000, p. 20). The acknowledgement of diversity is an aspect that plays a huge role in multicultural societies, which is often still lacking in research and campaigns. Sison (2009) compared twelve campaign entries in Australia, which is a country that is known for its multicultural publics, and found that only three of them discussed cultural variables. On top of that, these three campaigns focused on 
nothing but race and language as cultural factors. The issue of not having common history, expectations, and demands but still treating each other with respect and in an inclusive way is a challenge that multicultural societies are constantly dealing with (Parekh, 2000). In order to overcome distrust and ethnocentrism, people need to learn to accept and recognize cultural otherness and differences (Moosmueller \& Schoenmuth, 2009; Rock \& Koeck, 2004). The development of multicultural societies calls for an adjustment of practitioners that are responsible for effective communication between organizations and their publics. This fast-paced environment, thus, asks for quick reactions and responses that are appropriate and effective towards people with different cultural backgrounds and expectations at the same time.

\section{PR Practitioners in a Multicultural Environment}

The main question that occurs here is: How can PR practitioners develop campaigns that make it possible to reach out to target audiences in western, originally individualistic cultures where multicultural societies are becoming more and more common? In order to fit the needs of multicultural communities, PR practitioners need to be aware of all the various types of communication playing into it.

The task of a PR practitioner is the development, adaptation, and transmission of messages that "advance the interests of the client to the target public" (Parkinson \& Ekachai, 2006, p. 70). As Parkinson and Ekachai (2006) make clear, in order to work expansively and reach mass audiences effectively, PR practitioners first of all have to focus on their own mindset, thus intrapersonal communication. Besides that, practitioners have to become aware of their subconscious use of ethnocentrism, which is the placement of their own culture at the center (Kim, 2001; Parkinson \& Ekachai, 2006). Interpersonally, they should be aware of small group settings that influence their thoughts and needs, internally as well as externally. In a multicultural 
environment, practitioners require the ability to adjust themselves quickly and come up with solutions that appeal to target audiences with various backgrounds (e.g., Corella \& Herrera, 2011). Allen and Dozier (2012) recommend having cultural diversity among PR practitioners of any given entity in order to address culturally diverse publics effectively. PR practitioners have to be aware of the country's cultural dimensions since they function as cultural mediators (Curtin \& Gaither, 2007; Hodges, 2006) to communicate between clients and their customers who all bring in their own cultural identities. Therefore, L'Etang (2012) refers to PR practitioners in a multicultural society as "culture-workers" (p. 219).

One known challenge is people's inability to understand and explain their own culture effectively to others; it is often taken for granted since people do not think or discuss their own cultural background and values often (Brislin, 2001; 2006). That is why, it is necessary for PR practitioners to learn specific skills that make them effective intercultural communicators (Gudykunst \& Kim, 2003).

\section{Theoretical Framework: Intercultural Communication Competence}

In order to be successful in a multicultural setting where it is necessary to pay attention to individuals with various cultural backgrounds that have to be targeted at the same time one major skill to develop is intercultural communication competence (ICC). Spitzberg (2015) developed a model that takes into account the aspects that make up competence, the factors that influence it, and the "location" of competence.

First, it is important to understand the notion competence. Spitzberg and Changnon (2009) discuss the various criteria that scholars use to explain the meaning of competence, which are understanding, relationship development, satisfaction, effectiveness, appropriateness, and adaption. Specifically, Spitzberg (2015) sees intercultural competence as including two 
dimensions - effectiveness and appropriateness. Effectiveness refers to "an individual's ability to produce intended effects through interaction with the environment" (p. 217) with the intention to reach the valued goals. Appropriateness is connected to the ability to adjust the behavior (actions) and language to different norms and rules, depending on the situation. For example, these might relate to Grice's (1975) guidelines to appropriateness, such as saying enough for the situation, saying the right thing, adjustment to the situation, topic, and clarity of dispatch.

These guidelines are often seen in connection with specific skill sets. The problem with such a connection, however, is that it is not possible to use a universal approach to explain competence (Spitzberg, 2000, 2007). Therefore, when using the term competence in an intercultural approach, Spitzberg and Changon (2009) focused on the relevant conceptualizations of it that refer to "the appropriate and effective management of interaction between people who, to some degree or another, represent different or divergent affective, cognitive, and behavioral orientations to the world" (p. 7). Thus, the definition of communication competence in general can extend to include contextual factors. Chen and Starosta (2008) argue that communicators should look at "cultural commonalities and move beyond cultural differences in order to reach the ideal goals advocated by cultural dialogists and cultural critics" (p. 217).

Spitzberg (2015) was the first one to conceptualize intercultural communication competence in form of a model that would take a more integrative approach to it in terms of the locus of competence, or "where" competence occurs. He divides the factors that impact competence into individual system - the characteristics a person brings with them to an intercultural interaction, episodic system — the aspects of the interaction itself, and relational system — or characteristics individuals develop working with each other over time, such as mutual trust. What, however, plays a central role on all of these levels, are both interactants' 
"motivation to communicate, knowledge of communication in that context, and skills in implementing their motivation and knowledge" (p. 380) as the effective determinants for perceiving each other as interculturally competent.

Spitzberg's (2015) original model experienced many modifications and adjustments, by himself as well as other scholars. Whereas scholars kept the basic concept of competence, they changed or adjusted some variables to a specific part of ICC. Kim (1988) included individual tempers in form of predispositions and contextual conditions in her adjusted ICC model to explain how adjustment to the cultural orientations between intercultural communicators takes place. Ting-Toomey and Kurogi (1998) include criteria that focus more on behavioral and outcome factors, for example facework and mindfulness, that can be used for research that is aligned with politeness and facework management theory. Arasaratnam (2008) focuses on causes and effects of intercultural communication competence and has conducted several surveys to find out how collective variables, for example empathy and global attitudes, predict the motivation to have interculturally adjusted interactions. These are only a few examples that demonstrate the scope and breadth of the ICC model.

Moosmueller and Schoenhuth (2009) explored what role intercultural competence plays in German discourse and compared its development to the one in the United States. The intercultural communication competence publications in Germany mainly make use of American publications and use their knowledge and advice as an orientation (Hammer, 1998; Moosmueller \& Schoenhuth, 2009). As the two scholars point out, it was not as narrow and focused as in the US since its growth happened in a variety of fields, which is reflected in its fields of practice nowadays (e.g., education, linguistics, business). Specifically, the particularities of the conceptualization of intercultural competence in Germany consist of "critical reasoning, the 
attempt to integrate systemic aspects and the tendency to prefer the growth approach over the efficiency approach" (p. 210). However, for Germans, it can be more difficult to admit cultural differences and address this topic openly because of their history; people in Germany tend to equate cultural differences with racism and want to avoid associations like these. That is why the advancement of ICC concepts in Germany can be challenging for researchers.

\section{Rationale and Research Questions}

The existing literature and research reveals that the awareness of cultural dimensions and their clash in multicultural societies plays a crucial role for contemporary PR practitioners who seek to work effectively and design campaigns that are adjusted to the needs of the publics (e.g., Busching, Gentile, Krahe, Moeller, Khoo, Walsh, \& Anderson, 2015; Ginesta, Ordex, \& Rom, 2017; Rebeil Corella \& Herrera, 2011). Former research tends to mainly take an etic approach to cross-cultural studies that makes use of Hofstede's (1984) cultural dimensions and focus on communicational differences between individualistic and collectivist cultures, such as China and the United States (e.g., Jiang \& Wei, 2013). However, countries that are considered as culturally similar from an etic perspective sometimes still experience differences that have an impact on their communication behavior when being explored on an emic level (Ngai, 2000)

Two countries that are considered as similar culturally from an outside perspective (e.g., Hofstede, 1984, 2001) differ when explored from within. Several studies exposed cultural specifics that make a difference in Germans' and Americans' communicational patterns and business-related approaches, behaviors, and decision-making processes (e.g., Clackworthy, 1996; Friday, 1989; Hall \& Hall, 1990). Besides that, both countries are among the most effected by globalization in terms of high immigration numbers from various countries (Sriramesh \& Vercic, 2003; Statistisches Bundesamt, 2018; U.S. Census Bureau, 2016). The relevancy of practitioners' 
roles has changed in Germany and the United States: The new cultural environment demands a broader skills set that is not only focused on the development of interpersonal but also intercultural communication skills. This paper leads to the argument that PR practitioners in two individualistic, culturally similar countries that experience multiculturalism may perceive what is interculturally competent in terms of public relations practice differently, specifically when designing appropriate campaigns that address multiple diverse target audiences simultaneously. The study also has the goal to explore the role the different ICC elements, namely how motivation, knowledge, and skills are connected, play for the individual of PR practitioners, as well as their perceptions of the relational context in international PR experiences. These concerns lead to the following research questions:

RQ1: What role do participants feel culture plays in public relations practice in the United States and Germany?

RQ2: Which cultural dimensions and specific cultural influences do participants find relevant in their PR practice, specifically the development of campaigns?

RQ3: How do PR practitioners in Germany and the United States perceive appropriateness and effectiveness to play out when developing campaigns?

RQ4: What skills do PR practitioners perceive as necessary in order to work efficiently in the PR field, and do they adjust their PR practices to multiculturalism in these two countries?

RQ5: How motivated are PR practitioners to adjust their communication behaviors to target audiences with diverse cultural backgrounds?

RQ6: What challenges and benefits do PR practitioners perceive to multicultural public relations practice? 
These research questions aim to answer the bigger question, when considering the interdependence of culture and public relations, namely: What does all this mean for the practice of global PR?

\section{Conclusion}

This chapter explained the development in terms of globalization that leads up to the emergence of more multicultural societies and the need to be aware of the interdependence between culture and public relations. It not only demonstrated how it is important to conduct cross-cultural studies of countries that are different when being compared on an etic dimension, but showed the importance of taking an emic approach to explore the cultural specifics from an inside perspective. This led to a consideration of Germany's and the United States' PR development as well as cultural comparison on an emic and etic level. Since both countries are characterized by the emergence of multicultural societies, the theoretical framework focused on the development of intercultural communication competence.

Since all of the research questions focus on the exploration of PR practitioners' perceptions and experiences, this study will take a qualitative approach. The next chapter explains how I recruit participants to conduct in-depth interviews that will provide information about practitioners' perspectives in the United States and Germany, which allow for an emic-etic combined cross-cultural data analysis 


\section{CHAPTER III: METHODS}

As addressed in the literature review, it is important to see the interdependence between culture and public relations in our globalized world. The literature review explained how similarities in cultural background and dimensions can be found in the United States and Germany, but also emphasized differences in terms of cultural communication styles. This study makes use of qualitative interviews with PR practitioners of both countries to explore how perceptions of cultural similarities and differences affect them and their development of campaigns. The intercultural communication competence model will be utilized to examine participants' awareness and adjustment skills.

\section{Participants}

The participants consisted of public relations practitioners that are either residing and working in the United States or Germany. The requirement for their participation was that they be at least 18 years old, have received education or training in PR, and be currently working for a corporate organization, a PR agency, or an institution. The researchers and faculty members of a midwestern university recruited the participants through network sampling via email and social media posts (snowball sampling). The participation was voluntary and confidential. The PR practitioners who decided to participate contacted the researcher on their own volition via e-mail, without their work places or others knowing who participated. The total number of interviewees is 16 , with half of them working and residing in the United States and the other half in Germany. Since the purpose of a qualitative research project is not generalizability but rather an intense construction of cultural categories and the finding of relationships, according to McCracken (1988) "eight respondents will be perfectly sufficient" (p. 17) per country. 
All of the eight American participants work in Illinois, with six of them being female and two being male. One participant identifies herself as African-American, one identifies himself as Hispanic, born and raised in a South-American country with Spanish being his first language; the other six interviewees as White/Caucasian. Their ages range between 23 and 41 years. The majority, four of the participants, work for a PR agency, two of them in corporate, one for an institution, and one for a non-profit organization. All of the them have a college degree - seven a bachelor's degree and one with a master's. Besides one participant, everyone's major was related to communication studies or public relations. All of the American participants mentioned internships and practical experiences during their studies as part of the training and education in the PR field.

All but one of the eight German participants did not complete their degree or apprenticeship in a communication-related field. Four of them studied some type of social science, the other half did an apprenticeship in a business-related field, for example marketing and economics. The German participants are between 27 and 50 years old and come from different cities and federal states all over German, which provided more regional variance than the participant sample from the US, who were all practicing their PR in the same midwestern US state. Four of them were male, four female. One of the interviewees residing and working in Germany identified as Indian, the others as White/Caucasian. Three participants work in some type of PR-/Marketing-/Advertising agency, two (maybe three) in institutional PR, one for a start-up, and one (maybe two) in a global corporate.

\section{Data Collection}

The goal of this study was to find out more details about the experiences and perceptions of PR practitioners. Respondent interviews (Lindlof \& Taylor, 2011) are a useful method to gain 
these sorts of details. By using this method, I was able to get an in-depth insight about the interviewees' views, conceptualizations, and actions. Another advantage of respondent interviews is "that responses can be compared across the sample" (p. 180), which made it easier to see what the participants agreed on; thus, qualitative methods helped to identify recurring themes that were useful for the analysis. Further, the interviews were semi-structured. This method gave the interviewer the possibility to prepare questions ahead of time and to use them as a guide, but it also allowed the interviewer to vary the question wording and order when it seemed appropriate and useful for the research project (Cohen \& Crabtree, 2006). Besides that, semi-structured interviews simplify the comparability between respondents since they do not focus on the repetition of exact words and same vocabulary, but rather on the "equivalence of meaning" (Barriball \& White, 1994, p. 330).

\section{Procedure}

I interviewed the participants via Skype and recorded the audios. I am a native German speaker and fluent in English, which made it possible for me to offer to the German participants to conduct the interviews in their preferred language. Five respondents decide to receive the questions and/or answer in German. I translated segments of interviews used for analysis afterwards. This helped to avoid language barriers or misunderstandings. The interviews lasted between 25 and 55 minutes. I read an informed consent to the participants at the beginning of the interview, which confirmed confidentiality and got me their oral consent to proceed as well as

the permission to audio record them (Appendix A). The consent also provided more information about the project's content, purpose, risks, and benefits in order to achieve rapport (Lindlof \& Taylor, 2011). All procedures were approved by the university's institutional review board. 


\section{Interview Protocol}

The interviews started off with self-disclosure as I provided some information about myself, the project, and my research goals. The participants then provided some demographic information, as for example gender and education. Afterwards, a series of open-ended questions focused on their educational and training background, the procedure for the development of campaigns, and their awareness of the importance and impact of cultural dimensions. The interview protocol combined nondirective questions that left more freedom for the respondents to talk about specific terms and concepts (Lindlof \& Taylor, 2011) and structural ones that made them "think along certain lines or within certain parameters" (p. 207).

\section{Data Analysis}

\section{Coding, Unitizing, and Categorizing}

The first analysis stage consisted of the verbatim transcriptions of all of the interviews with participants who reside and work in the United States. In order to keep the confidentiality of the participants, I assigned pseudonymous names and did not mention the company name or anything else that could have revealed who they are or which company they are working for. While transcribing the interviews, I included reflections from former interviews and field notes, which reflected first ideas about the development of themes and conceptual categories. Furthermore, I added some commentaries and memos to the transcriptions that made it easier to compare the transcriptions for common themes that appeared to be repeated and emphasized as significant by multiple interview participants. Although the meaning and importance of some of these in-process writings changed, many of them appeared to have a beneficial impact on the following analysis stages, as described by Lindlof and Taylor (2011). 
The second analysis stage consisted of the development of categories for the American participants, with clustering of data elements/units that are similar in their representation of themes and concepts (Lindlof \& Taylor, 2011; Spiggle, 1994). I first went through the coding process, which is the systematic labeling of ideas that are relevant to the research questions. Second, I created a chart with three columns: category names, examples, and units included in category. The following step consisted of unitizing (Lincoln \& Guba, 1985), which made it possible to sort the transcripts into segments with the ideas that are relevant to the RQs, and added a third column with example quotes for the different units. The final step, categorizing, consisted of two parts: an inductive data analysis and the reference to previous theories and models. I did not only use low-inference but also high-inference categorization, which "require knowledge of cultural insider meanings or call for more complex decision rules for coding data" (p. 247). I then circled the units, which made it easier to clearly recognize similar themes connected to Hofstede's (2001) cultural dimensions and Spitzberg's (2015) model of intercultural communication competence. The focus was on codes and units that apply to Hofstede's expanded set of six dimensions, described in Chapter 2 as well as on the development of inductive categories to locate categories of knowledge, motivation, and skills (competence) that practitioners in the two countries use. This allowed the analysis to go beyond Hofstede's dimensions, and to conduct not only etic but also emic research. This interpretive content analysis was the most effective method for this study since it is a qualitative way to use coding and develop categories in a way that allows for a focus on complexity, and facilitates the translation of the raw data into meaningful symbols (Baxter, 1991).

I transcribed the German interviews in German or English, based on the language of the interview, providing translations into English of segments occurring in the final write-up. After I 
went through all of these stages for the data analysis for the American interviewees, I repeated the same steps for the German participants. The creation of these two charts with categories, units, and example quotes allowed for the comparison of similarities and differences between the German and American PR practice with the goal to answer the research question for this study.

\section{Establishing Credibility}

Lincoln and Guba (1985) discuss ways to strengthen qualitative research credibility, which relates to the truthfulness of a study's findings in terms of whether the researcher's interpretation would make sense to the participants in their own perception of reality. In order to establish credibility, I took several steps. First, a part of the data was set aside and was not analyzed until I finished the data analysis and the establishment of preliminary findings of one part. Then, I continued analyzing the rest of the data to see whether the results fit the existing categories, suggesting trustworthiness. Lincoln and Guba (1985) named this technique referential adequacy. I stopped the data collection and analysis when I either reached redundancy, which means that there was no new information available, but rather a repetition of it (Sandelowski, 1995). Finally, after the development of final categories, I did internal "member checks to

establish trustworthiness" (Lincoln \& Guba, 1985, p. 314), thus having later respondents verify how my interpretations of earlier interviews correspond to their own interpretations of their reality.

\section{Conclusion}

This chapter provided detailed information about the requirements for and the recruitment of participants through network sampling, and explained the usefulness of respondent semi-structured interviews that allowed for the exploration of practitioners' perspectives, perceptions, and experiences. It explained the three steps of coding, unitizing, and 
categorizing as part of the implementation of an interpretive content analysis. The following chapter presents the results of this analysis. 


\section{CHAPTER IV: RESULTS}

The purpose of this study has been to find out whether and how PR practitioners in the United States and Germany perceive the role of culture on their practice, specifically the development of campaigns. Therefore, a qualitative approach in form of in-depth interviews helped to explored their experiences. After the complete transcription of all interviewees' answers and the conduction of an interpretive content analysis, it was possible for me to clearly identify similarities and differences between the German and American PR practice. Some of the results reflected the influence of cultural dimensions and nuances; some demonstrated a connection to the specific culture of their company; and, then again, other parts were affected by personal experiences and circumstances.

\section{Definition and Perception of Public Relations}

Before addressing the research questions, it is important to understand how the perceptions and definition of the public relations term and field differ between American and German interviewees.

The American respondents used the same approach to explain the meaning and definition of PR by saying that it is the meditating of accurate information or messages between the company and its target audiences. Many of them, furthermore, mentioned the variety of subdivisions of PR, as for example crisis communication or event management. One of the main objectives that most American participants mentioned for public relations is the fulfillment of expectations and PR's purpose through the provision of the promised service. Among the German respondents, the answers differed widely, including defining public relations as getting in touch with clients, producing publicity for the client, building relationships between a 
company and the public, and having power over a story, or implementing change communication.

Peter, who is the head of communications and business development for a German startup company, summarized what most of the respondents in Germany mentioned several times throughout the interview: "In general, PR is a tool of company development, and also, it goes hand in hand with marketing. Often, you cannot really differentiate between marketing, PR, and business development." The majority of the Germans respondents do not see public relations as a separate field but rather as a part or subdivision of marketing and business development. Some of the Americans interviewees also talked about connections between the departments, but referred to them rather as an exchange of information, data, and expertise between the internal departments of public relations, marketing, and sales.

\section{Role of Culture in PR}

All respondents in both countries agreed that culture plays an important role for their work in the PR field, with a specific focus on the development of PR campaigns. However, their answers made clear that the understandings of the term culture as well as cultural values varied, not just between the two countries, but also among the participants of one country. Many of the interviewees had to ask for clarification or provided their own definition, emphasizing that they were hoping to answer the question about culture and cultural values correctly.

\section{National Focus}

Most participants from both countries are only in charge of designing campaigns for the nation where they reside and work. There was one global corporate PR practitioner respondent from each country, Germany and the US, as well as one American PR practitioner who works for a global agency; they were the only participants in charge not only of designing national but also 
global campaigns. Despite their involvement in the development of global PR campaigns, all of them agreed that the necessity to translate and the adjustment of campaigns to a bigger audience was just a small part of their work. They emphasized that the majority of their work is still connected to their nation's audience and culture since most global companies have regional specialists who make sure that the cultural values get addressed properly.

All of the remaining participants underlined that their main focus in terms of campaign development is only on the country where they reside. All Americans respondents stressed the importance of being culturally aware and the need of adjustment to multiculturalism even within one country or region because of the high cultural diversity, internally as well as externally. Two of the German participants shared this view; however, more than half of the German participants put their own country and language in the foreground when designing campaigns. They mentioned regional culture awareness as the most important cultural value - despite the existence of multicultural audiences. Hans, a 51-year old owner of a PR and marketing agency, made clear:

Everything is in German and for the German culture. I am only doing the regional PR part for companies, even if they are working internationally. For the campaigns that I produce here, the region plays a really important role, and you also emphasize the regional specificities.

Another example that demonstrates the focus on the native German-speaking population and lack of inclusion of other languages and backgrounds is a statement by institutional PR practitioner Manuela (age 27): 
In our case, one good example is that because of the cultural background a lot of our members have, we don't use English terms. So, we have to translate everything, even if it's a very common English term that everyone should know, as for example NGO.

\section{Cultural Values}

What participants of both countries also had in common was the reference to the importance of internal and external diversity. As mentioned earlier, nobody provided a clear definition of culture; many needed clarification for the terms culture and cultural values. Participants' answers showed that the term culture evokes an understanding of different types. Whereas half of the American participants named ethnicity, gender, age, educational differences, and family values as cultural values to pay attention to when developing campaigns, none of the Germans referred to educational differences or family values, and only two mentioned ethnicity and gender as important cultural factors. Peter, the communication head of the German start-up company, emphasized:

PR practitioners should not let culture influence their work too much. Sometimes, people exaggerate. Just because I use a Mohammed caricature as part of my PR and offend some people of the Muslim faith... since on the other hand I would betray my own values, my own culture, if I paid too much attention to imageries of other people.

This quote also shows two aspects that the German respondents tended to focus on more, which had not at all been mentioned by American PR practitioners: religion and politics. Whenever German respondents brought up examples of cultural diversity awareness, most of them mentioned Muslims. In the United States, most of the examples referred to ethnic minority groups, such as Hispanics and African-Americans. The only cultural element that the participants 
from both countries agreed on as an important factor is the diversity in terms of multiple age groups.

\section{Company Culture}

Respondents in both countries tend to put their company's culture over the meaning of culture in terms of diversity. In contrast to PR practitioners who work for agencies and are in charge of promoting their clients' brand, image, and story, the participants working for corporate, non-profit, and institutions focus on the promotion of their own reputation, mission, and engagement with the community. An example is a statement by non-profit worker Lauren: "We have to make sure that everything we do, aligns with our mission and vision. Because that's our heart. And we really put that out there, saying: This is who we are!"

They also reported the challenge of handling their in-house budget instead of handling the amount the client is willing to spend. Many of the American participants found their experience across different types of PR companies useful to incorporate into their current position. Only one of the German respondents mentioned these items, but rather the Germans focused on the importance of representing their current company's values, traditions, mission, and vision over the cultural values of their target audiences.

We, generally, pay attention to our target audiences, but we also have our own values, vision, and mission defined as a company. And if necessary, we push that on our users, thus our clients, because we think that it's right. That means, we do not just say what the consumers want to hear, because if we did, we would lose our identity as a company.

This quote by German respondent Peter also demonstrates typical German communication styles of directness and bluntness (Hall, 1976) that can be influential during the development of campaigns. The American respondents did not use this type of wording throughout any of the 
interview, but rather expressed their company value as an equally important part with emphasis on cultural awareness of and sensitivity towards their target audiences. Katy (age 41), who has had work experience in corporate and agency and is now the director of PR at a regional American non-profit organization, emphasizes: "Looking at our non-profit company and our mission of eliminating racism, we're trying to target every culture in this area. We try be very conscious of: 'Am I using the right word? Am I gonna offend anyone?’”

Almost all of the American participants expressed their interest in raising more awareness about cultural diversity and the willingness to learn more and work on a global level. Only the few German participants who talked about their international work and study experience expressed similar feelings and thoughts.

\section{The Impact of Multicultural Experiences}

The American as well as German participants with a more intercultural background, be it through their experience as a minority group member, their background of growing up in a different country, or their involvement through international study and work, expressed that these experiences might have altered their view and made them become more aware. Most of the American respondents who do not have any of these experiences admitted their lack of intercultural education and training. In both countries, only a few participants received professional intercultural or cross-cultural training.

Caucasian participant Beth, who is residing and working for a local agency in the United States, admits: "I must say that, unfortunately, I am not very culturally diverse. I've never travelled outside of the United States." African-American agency worker Megan, on the other hand, points out: "I feel like I'm being very well aware of the cultural values of the audiences because I am a minority." 


\section{Cultural Dimensions}

On the one hand, specific cultural values and influences provide an emic view of similarities and differences that affect the PR practice, specifically the development of campaigns. On the other hand, respondents referred to terms and concepts that are aligned with some of Hofstede's (2001) cultural dimensions, which contribute to etic research results. On Hofstede's official website (Hofstede Insight, 2018), the United States scores lower on masculinity, uncertainty avoidance, and long term orientation than Germany. The results of this study, however, display the opposite for all of the mentioned cultural dimensions.

\section{Masculinity}

Aside from the non-profit PR practitioner, all of the other American interviewees focused on being the best and saw success as the most important outcome at work. The striving for outshining competitors, being rewarded through client satisfaction, and reaching of monetary goals emerged as clear common results among the American participants that are aligned with Hofstede's (1984) cultural dimension definition of masculinity. Sidney, who works as a marketing and communication director for an American corporate, mentioned several times throughout the interview the importance of being successful and getting rewarded:

Everybody loved the media we got them... I think the best part was delivering what we had promised, like actually being able to get media being interested in them and getting the public eye ... and that our media relations helped them meet their donation goal is definitely a big accomplishment, makes us feel good.

In Germany, success was mentioned by some of the respondents but did not appear to play as much of a big role as other factors. The campaign measurement does not focus as much on success as in the US, and only a few participants mentioned the necessity of being rewarded 
and acknowledged. When being asked about received critique or failures that happened to them while designing campaigns, none of the Americans could think of any. Many of the German respondents talked about mistakes that happened and referred to mishaps and failures as helpful learning tools for the future. These findings are not concordant with Hofstede's (Hofstede's Insight, 2018) comparison where Germany scored higher than the United States in terms of masculinity.

One German respondent told personal stories about failed campaigns that did not take cultural values into consideration and resulted in lot of criticism from different target audiences, and concluded: "Whether it's going well or bad, you learn for the future. And that's the case here, we still try out a lot of different things."

\section{Uncertainty Avoidance}

The same quote reflects Germans' view on uncertainty avoidance when creating campaigns. Their willingness to take risks and rather fail but learn through it, as well as the acceptance of ambiguity and unpredictability reflects a lower uncertainty avoidance (Hofstede, 2001). Only one of the German participants mentioned the importance of thinking ahead as an important skill. A comparison of their answers to the ones by the Americans respondents makes it clear that uncertainty avoidance plays a bigger role in the American PR practice where several interviewees talked about the significance of having a forward-looking eye, the need for stability, and the avoidance of expanding their markets to other countries because it results in uncertainty. Sidney, for example, mentioned the fear of uncertainty as one reason why the company has not expanded its market to other countries: "It's just the unknown, it's that level of uncertainty when we adjust it to, for example, Canada, or whoever." 


\section{Long-term orientation}

According to Hofstede (2009), societies that focus on traditions and do not adjust as easily to newer concepts and change take a short-term approach. None of the American participants named traditions as valuable when designing campaigns. Although all of the participants referred to digitalization and social media as the biggest game-changers when designing campaigns, many of the German respondents admitted that their companies or institutions are having a hard time accepting this change and adjusting their strategies to it. On the other hand, the implementation of these has been referred to as much more positive and less of a burden in the United States. Besides that, German PR practitioners admitted their focus on more conservative tools when comparing their use of media channels and strategies to the American system.

Amanda, who has had a lot of different international study and work experiences and is an internal communications manager working for a global corporate in Germany, noticed that the typical German values connected to traditions, regulations, and critical thinking, affect her company's approach toward change:

Germans tend to be more critical about events, campaigns, anything that is presented to them ... And a lot of people in Germany are so, so critical about digital, so critical. Especially people on top don't understand as much, nobody understands what industry 4.0 is... It's just a hesitant and resistant digital culture, so it's very difficult with such topics.... this is not the case in other cultures, other regions, and other companies outside of Germany.

In comparison to the answers by all respondents, other cultural dimensions, like indulgence versus restraint, power distance, and individualism versus collectivism, did not 
appear to be salient to the PR practice, specifically the development of campaigns. However, the participants' answers gave insights about practitioners' willingness and ability to develop intercultural communication competence.

\section{Development of Intercultural Communication Competence}

As mentioned earlier, the development of intercultural communication competence (ICC) is a combination of someone's effectiveness; thus, the accomplishment of a task itself, and appropriateness, which refers to the ability to being following the cultural norms of the interaction (Spitzberg, 2015).

\section{Effectiveness}

Since the main focus of a public relations campaign is the achievement of an objective, it is important that the right strategies be used in order to work effectively and efficiently. A significant role of public relations is to avoid failures through exclusion or misunderstandings. Therefore, it makes sense that all American and German participants emphasized how important it is to reach multiple audiences simultaneously with one campaign. The combination of strategies in terms of combining multiple platforms and adjusting communication styles to address different age groups occurred as a common theme among all of the respondents. When being asked about the strategies that the interviewees make use of for their campaigns, they provided the following two most common answers: "Print, digital, face-to-face ... All of them!" and "Whatever works best for our client and the target audience."

More than half of the participants in both countries, furthermore, talked about the necessity of being able to adjust to changes; all of the American respondents focused on the term "trends" in that context, whereas many Germans talked about changes along the way, as a reaction to the "analytical assessment of the campaign." Besides that, a few Germans 
emphasized how important it is to admit mistakes, to apologize for them, and to copy and learn from others. On the contrary, the majority of the American respondents referred to the opposite, namely the avoidance of any mistakes through "review and revision" and the ability to "switch angles." As one American respondent said, "You definitely have to be aware of the messaging that you're putting out there. You don't want to promise something that you can't deliver on."

\section{Appropriateness}

In order to also interact appropriately while being effective during the development of campaigns, the most important part to adjust is language, as almost all of the respondents mentioned. However, the Germans referred to the term language in a different way than the Americans. While the focus in the US is on the wording and message itself, the emphasis in Germany is on the visual material that they call Bildersprache, which literally translates to "imagery language." Peter is one among some German respondents who is aware of the

diversity in terms of religious values and explains how something that might be normal for some regions and beliefs could be very offensive for others:

We use different types of Bildersprache, depending on the markets. In Bavaria it would be funny to incorporate a cow in your campaign and the audience would love it, whereas in Asian markets you couldn't for example use cows on your campaign; since it is sacred, it would have the opposite effect.

This example again shows how the earlier mentioned values of the political and religious environment have a higher impact on awareness and appropriateness in Germany, whereas adjustment to the diverse ethnic groups is at the center of American appropriate communication in PR campaigns. Penny, a Caucasian woman working for an agency in the United States, talked about addressing minority groups with someone who they can identify with: "If we're using a 
spokesperson, we wanna make sure that we're using someone who's more like the audience they're talking to." The majority of the American respondents also expressed the importance of an intercultural expertise exchange with external and internal departments on a national and global level in order to avoid exclusion and be culturally appropriate, as for example the Caucasian director of the communication and public relations of a non-profit organization: Here, what's always at the forefront is, you know, I have somebody on staff who might be from a different culture, and I might go to them and say: 'Hey, is this the right way to say this?' Just to make sure to be culturally appropriate and not excluding certain cultures.

A few of the American and German participants talked about the importance of timing and consideration of holidays and specific heritage celebrations as an important factor for having appropriate interactions. Amanda, who works for a German corporate but has Indian heritage, emphasizes:

It also comes back in terms of timing - how do you choose a time for these audiences a year? You have to make sure it doesn't clash with a lot of corporate events. But then, one of the biggest considerations is the awareness of people of Muslim faith who celebrate Ramadan. So, there the cultural issues come in... we push the campaign around to avoid religious issues.

The interdependence and interconnectivity between appropriateness and effectiveness is necessary in order to be interculturally competent. The parts that contribute to this interdependence are motivation, knowledge, and skills of the PR practitioners. 


\section{Knowledge}

In order to handle appropriately and effectively, communicators need to gain knowledge about their own and others' frame of reference, cultural backgrounds and identities to understand how these impact perceptions, expectations, and interactions. The interview results reveal that people with international study and work experience or diverse backgrounds tend to be more sensitive and knowledgeable about the scope of cultural differences and effective strategies for adjustment. Amanda, working and residing in Germany with various international study and work experiences, is convinced that these experiences make it easier for her to comprehend the importance of intercultural awareness:

I think that probably comes from the fact that I have a very diverse background. I have an Indian heritage, I have an Arab work place, work ethic culture, I have an American work culture because I've pretty much taken all types of worlds, and kinda adapted it to my fabric.

She, as well as most other participants in both countries, agree that practical experiences are a lot more valuable and useful than anything they learned in college. In Germany, three participants received some type of cultural education through their studies; nobody besides the corporate PR practitioner has had any form of training at any of their work places. In the United States, almost all of the participants took intercultural communication classes but also had only two who had training.

\section{Motivation}

Besides being knowledgeable, another factor that affects the development of intercultural communication competence is the motivation, in this case feelings connected to interest and curiosity between communicators. While none of the German participants expressed a desire for 
the implementation of intercultural or similar training, all of the American respondents showed enthusiasm and interest in expanding their cultural knowledge and awareness theoretically and practically. Megan, for example, showed excitement about learning about and from other cultures' PR practice. She valued "working for accounts that give me the opportunity to travel and plan events on behalf of my clients in order to get them portrayed and the messages they'd like portrayed. And that's something I'm really thankful for."

The comparison of answers showed that there are a few German practitioners who also enjoy the opportunity of learning from other countries in terms of campaign development. The majority of the American respondents, however, expressed more enthusiasm about the chance to exchange expertise with culturally diverse people, internally and externally, on a national and global level to get a better understanding of intercultural differences and being able to work towards market expansion. The results also revealed that American companies, no matter which type, are putting a lot of effort into effective partnerships and cooperation with charities and nonprofit organizations to raise awareness in the community. Passion for what they are doing and the opportunity to get to know other cultures, communities, and experience versatility through their job in the PR field emerged as a common theme. Katy, who has worked in corporate and agency before and is now in charge of non-profit institutional PR, expressed her enthusiasm about her work: "Spending time with the communities, and working in community relations; they were always the favorite parts of my job."

A few German participants are also motivated and curious about learning from other cultures and adjusting their campaign development to various target audiences, which they see as a positive and exciting challenge. They emphasized how important it is to keep up traditions for 
their loyal clients and audiences but be open for new trends and changes at the same time. Manuel, a PR and marketing agency owner from Germany, stated:

The highest competence that someone can have is that I am being convinced of what I'm doing. And that might sound too emotional for some people, but it really is the highest efficiency in its application ... I believe you need a lot of emotional creativity in this field. You have to walk through life with an open mind and an open heart.

\section{Skills}

In addition to the knowledge and motivation components, the development of specific skills is also necessary in order to have appropriate and effective interactions (Spitzberg \& Cupach, 1984). Since all of the participating PR practitioners emphasized the importance of adjusting their communication style to their specific clients and target audiences, this section explores and compares how this procedure functions in the United States and Germany.

The majority of the respondents in both countries find the abilities to think critically and plan strategically very important. This goes hand in hand with being flexible in terms of individual adjustment to the needs and expectations of their different target audiences. The majority of the German and American respondents believe in creativity in order to come up with appealing messages for different target audiences.

All but one of the Americans agreed on effective communication and writing skills as the two most important skills to have and emphasized the importance of taking their own bias out and paying close attention to details and cultural nuances. As one American PR practitioner phrased it: "Sometimes PR practitioners have to switch angles to target those that might be different than targeting mainstream audiences." The German respondents, on the other hand, focused less on the specific cultural differences but rather named being analytical as one of the 
most impactful skills. As a German PR practitioner with international study and work experiences pointed out, "You have to be a good observer, you have to be analytical. And I think, this is debatable between countries, the analytical part, because in Germany you need so much of it than in the US."

Interpersonal communication skills in terms of adjusting to different types of people have been mentioned by some American and German participants. They, specifically, focused on the importance of being able to listen and read people first, before trying to influence them. One German respondent talked about the "ability of being empathetic" and came back to that point throughout the interview.

\section{Challenges and Benefits of Multiculturalism and Globalization for PR Practice}

Globalization and multiculturalism both have positive and negative sides and can be beneficial and challenging at the same time. As one German participant pointed out when talking about the impact globalization has on the development of campaigns and the PR practice: "Where there's light, there's shade. Every positive thing comes with its negatives."

\section{Social Media and Digitalization}

As mentioned before, all of the participants in the United States and Germany agreed on digitalization, new technology, and social media being the biggest "game-changer" and influencer on the development of campaigns. On the one hand they expressed their appreciation for it in terms of being able to spread messages faster and to a broader audience; on the other hand, they mentioned concerns because of its nature that makes it possible for everyone to be an active participant and story-narrator. Lauren stated:

So, I think, that the ability that these outside forces have the ability to change your story.

Before you didn't really have to worry about that, before social media and all that stuff, it 
might have affected a group of friends that talked to each other, but now it can globally change your presence if that person had enough pull.

Some German participants also expressed their concern of "having more competition and a more difficult time to promote their service or product in a unique way."

\section{International Audiences}

Most participants in both countries agreed that a more international audience even within one country makes it more challenging in an exciting way to develop campaigns, but that it also gives them "more to worry about." They emphasized the necessity of being able to adjust one campaign to multiple and culturally diverse target audiences at the same time while also being aware of the changing trends, caused by globalization. Many respondents mentioned not only their own awareness but the difficulty of convincing colleagues or other stakeholders of cultural adjustment strategies. As German PR and marketing owner Richard points out, "We have to change the view of the clients, not the audience."

While in the United States all participants agreed on the important role of globalization on the development of campaigns and the importance of addressing a multicultural audience, there were a few participants in Germany that did not perceive its role as meaningful for their type of campaign development at all since they only want to reach out to specific regional audiences or cultural members. American respondents, furthermore, mentioned the difficulty of

coming to internal agreements of people, not just because of their different backgrounds but also because of personal preferences and priorities. Lauren experienced an interaction that made her aware of that issue and emphasized, "So, I think the personal differences that also come with the different cultures and the personal experiences, it's gotta be exhausting, every day to having to 
teach people these things, but if they don't learn it any other way, how are they supposed to be more culturally sensitive?"

\section{Challenges}

As mentioned earlier, in the United States the main concern is the fear of unintentional exclusion of different ethnic groups or misunderstandings between them through wording or the loss of meaning when translating. Felix, an American PR practitioner working for a German corporate in the United States, appreciates the opportunity to reach a broad audience in English but has to deal with translation issues from time to time, and concludes, "Language is not the biggest stressor, but still the main thing." In Germany, PR practitioners are worried about losing target audiences who do not support multiculturalism and companies that adjust their messaging to a more international audience. Peter explains:

Because of the current political situation in Germany where the right national party is getting bigger and bigger, we have to be more careful, even though it hurts, so that we don't become too multicultural; otherwise we will get comments like, "Rather buy your product somewhere else. This company supports the increasing influx of refugees in Germany.

Another aspect that half of the German interviewees named as challenging for the development of global campaigns or the appeal to multicultural audiences is Germany's bureaucracy in terms of stricter regulations, making sure to act in a legally correct way. As an international practitioner, working and residing in Germany, phrased it: "You know, the typical German way, always sticking to regulations and being critical about everything." 


\section{Benefits}

Despite these challenges, however, most participants in both countries also believe that newer generations, diversity among companies, and opportunities of expanding the global network and market are beneficial outcomes of globalization and multiculturalism. Many American participants appreciate the growing study abroad and travel experiences that make it possible to increase international cooperation and intercultural awareness and adjustment. German PR practitioner Manuel believes in a bright future in the PR field through the continuing change through globalization, and emphasizes, “There are no limits nowadays anymore, that's a huge achievement of digitalization, that we became more open in dialog with each other ... it also helps to reduce barriers, also cultural barriers."

\section{Conclusion}

The comparative interpretive content analysis of interview answers by American and German PR practitioners made it possible to find out what role the different experiences have on the development of PR campaigns and how participants perceive the diverse cultural influences and effects of globalization. Not only do their public relations education, training, and perception display differences, but also their attitude towards changing their approach and strategies in order to adjust to multiculturalism. Germans reported less sensitivity toward and interest in cultural diversity and sensitivity in public relations practice than Americans. However, when it comes to the development of intercultural communication competence, most of the practitioners in both countries have similar approaches to what has to be thought, felt, and done in order to communicate effectively and appropriately with various target audiences. They also agree on specific aspects of globalization and multiculturalism to be beneficial and challenging at the 
same time. The following chapter will demonstrate how these results relate to previous research, and how they can be useful in the future. 


\section{CHAPTER V: DISCUSSION}

The previous chapters explained through existing literature and experiences by respondents how globalization has changed the PR practice. This chapter summarizes the findings about the differences and similarities between the PR practice and its interdependence with cultural values with a focus on campaign development in the United States and Germany. It also adds on to the theoretical framework of Hofstede's cultural dimensions and the intercultural communication competence model, and provides practical implications for the PR practice in companies. After a summary of the strengths and limitations of the study, the chapter ends with suggestions for future studies.

\section{Summary of Findings}

As Martell (2007) and Friedman (2005) pointed out in their research, globalization brings transformation for companies since it allows for economic growth through multinational corporations as well as broader perspectives and new opportunities. This study clearly confirms these findings in the PR field. All of the American and German participants talked about new perspectives and transformation through technology and social media, and many mentioned the possibility of expanding and exchanging expertise and experiences with their international networks.

It was surprising that most of the PR practitioners in Germany did not have a common perception of public relations and provided definitions that are not aligned with the one that the DPRG (2018) in Germany as well as the PRSA (2018) in the United States refer to on their websites, namely the "strategic communication process that builds mutually beneficial relationships between organizations and their publics." Most of the American respondents used similar words to explain what public relations means to them, such as "building the bridge 
between company and public information." Germans rarely agreed on focused on different aspects, such as media relations, or spreading the word. An explanation for that could be the different education and training that the interviewees went through. While all but one of the American participants studied communication or PR, none of the Germans had any of these subjects as their major and also did not have as many practical experiences in the form of internships. What the participants from both countries, however, agreed on was the necessity of using effective strategies and tactics connected to critical thinking, strategical planning in order to adjust their messages to their target audiences, which shows that campaign development models like ROSTE can be applied successfully internationally (Parkinson \& Ekachi, 2006). All of the practitioners defined the role that culture plays in connection with public relations in various ways. American as well as German participants referred to background, values, and beliefs, which Hall (1976) and Kim (2001) named as some key components of culture. However, the focus on specific cultural influences differed between the practitioners of the two countries. While the American respondents mainly referred to the importance of taking different backgrounds in terms of ethnicity into consideration, Germans tended to focus on beliefs and religious differences. Many American participants brought up the Hispanic population as a culturally diverse group to pay attention to when developing campaigns; Germans used Muslims from Arabic countries as a typical example. Since the United States experiences the biggest influx of immigrants from Central- and South-American countries (U.S. Census Bureau, 2016), and Germany from Middle-Eastern ones (Statistisches Bundesamt, 2018), the results reflect how the current political situation in each context can also affect the PR practice. Besides that, regional cultural differences as well as age emerged as the two cultural factors that participants felt had the biggest impact on public relations in both nations. The 
respondents did not talk about the meaning of culture in their day-to-day PR interactions but referred to it in a more general way. Many of them acknowledged that they just started to think more about specific cultural aspects during the interview. They realized that it might not have played a big role for them but admitted that they should care more.

\section{Theoretical Framework}

This study took an emic approach, which made it possible to find out more about individual cultural influences, filtered through an etic lens that allowed for cross-cultural comparisons through the consideration of Hofstede's cultural dimensions. As previous research pointed out, the United States and Germany are highly individualistic countries (e.g., Hofstede 2001). In the context of public relations practice, however, practitioners experienced their work as more influenced by collectivism, especially in the United States where almost all of the participants focused on partnerships with charities, collaboration, and doing good for the community. The results of this study are also not aligned with former cross-cultural findings that emphasized the role of power distance in the public relations practice (Jiang \& Wei, 2013; Mustasha \& De Troyer, 2009; Sriramesh \& White, 1992). None of the participants discussed the importance of status and roles. However, Hofstede's $(2001,2009)$ cultural dimensions of masculinity versus femininity, uncertainty avoidance, and long-term versus short-term orientation play an important role when comparing the PR practice with a specific focus on campaign development in the United States. The results of this study are the opposite of the general cultural dimension comparison provided on Hofstede's (Hofstede's Insights, 2018) website, where Germany scores higher in terms of masculinity, uncertainty avoidance, and longterm orientation. The answers of the participants, however, indicate that American PR practitioners are a lot more focused on success and predictability, more open towards change, 
and less focused on traditional values when developing campaigns, which contradicts expectations based on lower masculinity, less uncertainty avoidance, and lacking long-term orientation. As mentioned earlier, the participants went through different educational and training programs, which might explain these outcomes in terms of Hofstede's dimensions. While all but one of the American participants studied communication or public relations and completed several internships, only one of the German participants received a degree in a communication-related field. The American respondents perceived public relations as a separate field and were trained to think and work collectivistically; they emphasized how important ongoing training and information-exchanges with other business-related departments, as for example marketing or business, are. Many German interviewees, on the other hand, put more focus on the marketing and advertisement part when developing campaigns, and did not perceive specific studies or training in the PR field as a necessity.

In terms of the development of intercultural communication competence (Spitzberg, 2015), it becomes clear that most American participants have either already developed it, or a higher tendency of becoming interculturally competent. The reason for this is their high motivation, expressed in curiosity and excitement for learning more about other cultures, the desire to expand their knowledge, and the willingness to acquire necessary skills through crosscultural training. Only a few German participants, on the other hand, find it necessary to be culturally aware as part of their job. The majority of them were not enthusiastic about receiving more education in this field and did not talk about the benefits but rather disadvantages of being too culturally sensitive, tolerant, and aware, which confirms the challenge of doing research incorporating the ICC model in Germany, as Moosmueller and Schoenhuth (2009) pointed out. Another explanation could be the ethnocentric character of the model since it has its origin, 
development and main application in the United States. As Spitzberg's (2015; Spitzberg \& Changnon, 2009) model demonstrates, the combination of the three components, motivation, knowledge, and skills, is necessary in order to communicate appropriately and effectively in a cultural context. The PR practitioners of both countries who talked about their international study and work experiences also emphasized the importance of adjustment and appropriateness. They provided personal examples that demonstrate how the combination of the three components that they bring in made it possible for them to develop ICC.

\section{Practical Implications}

A review of the aspects of the successful development of ICC (Spitzberg, 2015) should provide all types of companies, be they on a regional or global level, the education and training that furthers intercultural awareness and adjustment skills. Most of the American practitioners who have not had any international study or work experience admitted their lack of knowledge, but expressed their desire to receive such type of training. Many of the German participants did not even see the importance of being interculturally aware and did not perceive it as an influencing factor for their work, despite the increasing number of culturally diverse audiences in their country. It is important to incorporate classes into all types of studies and apprenticeship programs to prepare people for the change caused by globalization that eventually is going to affect most fields, especially the communication sector. The implementation of mandatory crosscultural training for PR/marketing/communication departments in all types of companies could help practitioners to develop intercultural communication competence. Previous research backs up the necessity of making use of more and better training opportunities to adjust to the ongoing PR practice to consistent change in our globalized world (Gregory, 2003). 
Companies could furthermore measure the intercultural competence of practitioners through a pre- and post-test in connection with the cross-cultural training. This could lead to the better employee selection for cross-cultural PR assignments. Some competence items are trainable implementation of more successful campaigns in the future (Landis, Bennett, \& Bennett, 2004). Since all of the participants agreed on the impact of social media on a more global, multicultural audience, this is another aspect that should be incorporated into the education and training of PR practitioners. Since the awareness among practitioners in the United States and Germany differs, the training methods and content could be adjusted to it. In this study, all of the Americans suggested more cross-cultural education and training, expressed their curiosity and motivation to learn more about other cultures, and noted their interest in global cooperations. The desire for more knowledge and skill acquisition can focus on the specific concepts that more experienced practitioners referred to. On the other hand, almost none of the German participants showed enthusiasm or interest in furthering their knowledge, which shows how important it is to start with motivational training for them and a demonstration of the advantages for them to become more interculturally competent. While the focus on training in the United States should be on cultural diversity in terms of ethnic differences, the one in Germany should rather be on religious and political awareness.

Raising the internal ethnic diversity, and having different representatives in terms of age and gender in companies is another important factor that many American and some German respondents mentioned in order to make the adjustment to change easier and to raise intercultural awareness. Previous research talks about "the benefits from recruiting from ethnic minorities and from the full range of social classes who bring in their in-depth knowledge and open-up access to wider stakeholder groupings" (Gregory, p. 12). Another positive outcome of this implementation 
could be a reduction of subconscious use of ethnocentrism (Kim, 2001; Parkinson \& Ekachai, 2006), which can lead to a better accommodation of different communication styles.

\section{Strengths and Limitations}

The biggest strength of this study consisted in the maximum variation, at least in some aspects, that the participants provided in terms of gender, age, and the type of company for which they work. The study provides insight into the various experiences that practitioners from different generations and cultural groups shared, and demonstrates that their cultural and personal differences in terms of age and education also influence their view on the role culture plays when developing campaigns. At the same time, in terms of ethnicity, it would have been helpful to have a more diverse sample. Only three of the 16 participant identified as nonCaucasian. It would be interesting to conduct a study with more diverse participants to see how their perceptions and experiences differ. Besides that, it was a limitation that all of the American participants came from the same midwestern state. In order to find out whether the results might be affected by that, it is necessary to get a broader sample, or to do a cross-cultural comparison with other American states.

The study revealed that participants with international study and work experiences are more aware of cultural differences and express the need of sensitivity and training. Unfortunately, none of the interview questions focused on participants' specific international experience or ability to communicate in more than one language, which could have been useful for the comparison of results. It would also have been interesting to include a question about the time of experience in the PR field to see whether and how it has an impact on specific perceptions that refer to the interdependence of culture and public relations. 
The inclusion of a question that asked participants what PR means for them showed a clear difference between the German and American perception of the field in general. To comprehend whether the same applies to the term culture, it would have been helpful to include a question about their perceptions and definitions of culture, especially, since many participants in both nations needed clarification for the meaning of cultural values.

None of the American and only a few of the German participants shared stories about mistakes that happened when being asked about campaigns by their companies that resulted in failure or criticism because of a lack of cultural awareness or unintentional exclusion. Since the conduction of qualitative in-depth interviews relies on the accounts and disclosure by participants, the fear of admitting mistakes (i.e., social desirability, face-saving) might have affected their answer. The strength of this in-depth, semi-structured interview design is its allowance for follow-up questions and clarifications, which was the case for the majority of the interviews and reduced the lack of understanding between the interviewer and respondents. Lindlof and Taylor (2011) admit the impossibility of categorization and coding being completely "free of ambiguity," but also emphasize the necessity of it in order to "push beyond the descriptive level" (p. 248).

\section{Future Research}

Future studies need to differentiate more between different types of PR in terms of companies. The results revealed that the company culture and type of work also affect the development of campaigns and the cultural focus of PR practitioners. Specifically, the PR practitioners working for global corporate companies were able to share their experiences with the development of global campaigns in more than one language and for different countries. In order to understand how multiculturalism influences public relations on a national or an 
international level, future research should differentiate between national and global agencies, corporate companies, institutions, and non-profits. Besides that, it could be helpful not only to use qualitative methods in terms of interviews but instead a combination of interviews and contextual analysis to see whether the respondents' answers are reflected in their campaigns. Furthermore, a quantitative approach could be useful to see how the etic view, as for example Hofstede's $(2001,2009)$ cultural dimensions, play out in those countries to add to the theoretical framework.

As mentioned earlier, a broader sample of American participants from different regions from all over the United States should be used in the future cross-cultural comparison studies. It would also be interesting to expand the comparison to other individualistic countries with similar cultural backgrounds to see how the three cultural dimensions, long-term versus short-term orientation, masculinity versus femininity, and uncertainty reduction, play out in connection with the development of PR campaigns.

Since all of the participants emphasized that social media and digitalization have been the biggest change-factor, simultaneously resulting in benefits and challenges for the development of PR campaigns, future research should focus on this aspect when examining how cultural influences and the PR practice are intertwined. It could be interesting to see how PR practitioners manage multiculturalism in terms of visual material and language, and how they make sure to not offend people with different religions and ethnicities.

This study combined an emic and etic approach by not only looking at cultural dimensions from a broad, general view but also paying attention to cultural nuances that are often not taken into consideration. Since most previous research only takes one approach or the other, it would be interesting to see a combination of both more often in future studies. 


\section{Conclusion}

After a review of the existing literature and the analysis of answers by German and American PR practitioners, the results showed how important it is to use an emic and etic approach to draw the connection to existing research that highlights cultural nuances as well as exemplifying existing theories. The study revealed that it is important not to generalize or make assumptions about the work in two countries that appear to be alike in terms of cultural dimensions, but to go a step further and see the specific cultural differences that affect the work and its outcome, especially, in a world that is becoming more and more multicultural. This study provides information about strengths and limitations, practical implications in terms of the need for more cross-cultural education and training, as well as future directions to combine emic and etic approaches and to narrow the sample down to retrieve results that can be applied in specific types of companies and countries. More research is necessary that makes practitioners aware of the importance of developing intercultural communication competence. Globalization and multiculturalism are going to affect our personal and professional lives more than ever, and people need to be educated on the growing impacts. As one participant said:

"I would just say, with culture and public relations, the main thing just is starting with awareness. Realizing that one size does not fit all, and everything that you're doing, you have to adjust, you have to be ready to change because that's, I think, the foundation of the industry." 


\section{REFERENCES}

Allen, M. R., \& Dozier, D. M. (2012). When cultures collide: Theoretical issues in global public relations. In K. Sriramesh, \& D. Vercic, Public relations: Links and implications (pp. 182-201). New York, NY: Routledge.

Appadurai, A. (1996). Modernity at large: Cultural dimensions of globalization. Minneapolis, MN: University of Minnesota Press.

Applebaum, R. P. \& Robinson, I. (2005). Critical globalization studies. New York, NY: Routledge.

Arasaratnam, L. A. (2007). Research in intercultural communication competence. Journal of International Communication, 13(2), 66-73. doi: 10.1080/13216597.2007.9674715

Austin, E. W.., \& Pinkleton, B. E. (2015). Strategic public relations management: Planning and managing effective communication campaigns (3rd ed.) New York, NY: Routledge.

Baldwin, J. R. (2018). Evolving definitions of culture and intercultural communication for emerging global realities. Submitted for publication in W. Jia (Ed.), Intercultural communication: Adapting to emerging global realities: A reader (2nd ed., pp. 27-43). San Diego, CA: Cognella.

Baldwin, J. R., Coleman, R. R. M., González, A., \& Shenoy-Packer, S. (2014). Intercultural communication for everyday life. Malden, MA: Wiley-Blackwell Publishing.

Baldwin, J. R., Faulkner, S. L., Hecht, M. L., \& Lindsley, S. L. (Eds.) (2006). Redefining culture: Perspectives across the discipline. Mahwah, NJ: Lawrence Erlbaum Associates.

Banks, S. P. (2000). Multicultural public relations: a social-interpretive approach. Ames, IA: Iowa State University Press. 
Bardhan, N. \& Weaver, C. K. (2011). Public relations in global cultural contexts: Multiparadigmatic perspectives. New York, NY: Routledge.

Barnard, A., \& Parker, C. (2012). Campaign it!: Achieving success through communication. Philadelphia, PA: Kogan Page.

Barribal, K. L., \& White, A. (1994). Collecting data using a semi-structured interview: A discussion paper. Journal of Advanced Nursing, 19, 328-335. doi: 10.1111/j.13652648.1994.tb01088.x

Baxter, L.A., (1991). Content analysis. In B. M. Montgomery \& S. Duck (Eds.), Studying interpersonal interaction (pp. 239-254). New York, NY: The Guilford Press.

Bentele, G. (1997). Grundlagen der Public Relations. Positionsbestimmung und einige Thesen [Public relations basics. Determination of positions and some theses]. In: W. Donsbach (Ed.), Public Relations in Theorie und Praxis: Grundlagen und Arbeitsweise der Öffentlichkeitsarbeit in verschiedenen Funktionen (pp. 21-36). Muenchen, Germany: Reinhard Fischer.

Bentele, G., Seidenglanz, R., \& Fechner, R. (2015). Profession Pressesprecher 2015: Vermessung eines Berufsstandes [Profession press spokesperson 2015: Measurement of a profession]. Berlin, Germany: Bundesverband deutscher Pressesprecher.

Bentele, G., \& Seiffert, J. (2012). Public relations and culture in Germany: Between the "iron cage" and deliberative democracy. In K. Sriramesh \& D. Vercic, Public relations: Links and implications (pp. 124 - 143). New York, NY: Routledge.

Berry, J. W. (1990). Imposed etics, emics, derived etics: Their conceptual and operational status in cross-cultural psychology. In T. N. Headland, K. L. Pike, \& M. Harris (Eds.), Emics and etics: The insider/outsider debate (pp. 28-47). Newbury Park, CA: Sage. 
Brislin, R. W. (2001). Intercultural contact and communication. In L. L. Adler \& U. P. Gielen (Eds.), Cross-cultural topics in psychology (2nd ed.) (pp. 213-228). Westport, CT: Praeger.

Brislin, R. W. (2006). Culture and behavior: An approach taken in psychology and international business. In J. R. Baldwin, S. L. Faulkner, M. L. Hecht, \& S. L. Lindsley (Eds.), (pp. 8390) (2006). Redefining culture: Perspectives across the discipline. Mahwah, NJ: Lawrence Erlbaum Associates.

Busching, R., Gentile, D. A., Krahe, B., Moeller, I. Khoo, A. Walsh, D. A., \& Anderson, C. A. (2015). Testing the reliability and validity of different measures of violent video game use in the United States, Singapore, and Germany. Psychology of Popular Media Culture, 4(2), 97-111. doi: 10.1037/ppm0000004

Cai, D. (1998). Issues in conducting cross-cultural research. In J. N. Martin, T. K. Nakayama, \& L. A. Flored (Eds.), Readings in cultural contexts (pp. 29-38). Mountain View, CA: Mayfield.

Casmir, F. L. (1999). Foundations for the study of intercultural communication based on a third culture building model. International Journal of Intercultural Relations, 23(1), 91-16.

Chen, G., \& Starosta, W. J. (2008). Intercultural communication competence: A synthesis. In M. K. Asante, Y. Miike, \& J. Yin (Eds.), The global intercultural communication reader (pp. 215-238). New York, NY: Routledge.

Clackworthy, D. (1996). Training Germans and Americans in conflict management. In M.B. Editor, Cross-cultural team building (pp. 91-100). Cambridge, MA: McGraw-Hill. Clifford, J. (1997). Routes: Travel and translation in the late twentieth century. Cambridge, MA: Harvard University Press. 
Cohen, D., \& Crabtree, B. (2008). Qualitative research guidelines project. Retrieved on January 7, 2018, from http://www.qualres.org/HomeSemi-3629.html

Collier, M. J. (1994). Cultural Identity and intercultural communication. In L.A. Samovar, R.E. Porter, E.R. McDaniel, C. S. Roy. Communication between cultures (pp. 53-60). Boston, MA: Cengage Learning.

Courtright, J., Wolfe, R., \& Baldwin, J. (2011). Intercultural typologies and public relations research: A critique of Hofstede’s dimensions. In N. Bardjan \& C. K. Weaver (Eds.), Public relations in global cultural contexts: Multi-paradigmatic perspectives (pp. 108139). New York, NY: Routledge.

Croft, A.(1999). Managing a public relations firm for growth and profit (2nd ed.) New York, NY: Routledge.

Curtin, P. A., \& Gaither, T. K. (2007). International public relations: Negotiating culture, identity and power. Thousand Oaks, CA: Sage.

Cutlip, S. M. (1995). Public relations history: From the 17th to the 20th century. Hillsdale, NJ: Lawrence Erlbaum Associates.

Cutlip, S., Center, A., \& Broom, G. (2000). Effective public relations (8th ed.). Upper Saddle River, NJ: Prentice Hall.

Davidson, A. R., Jaccard, J. J., Triandis, H. C., Morales, M. L., \& Diaz-Guerrero, R. (1976). Cross-cultural model testing: Toward a solution of the emic-etic drama. International Journal of Psychology, 11(1), 1-13. doi: 10.1080/00207597608247343

Debeljak, A. (2012). In praise of hybridity: Globalization and the modern western paradigm. In K. Sriramesh, \& D. Vercic (Eds.), Public relations: Links and implications (pp. 243-257). New York, NY: Routledge. 
Deutsche Public Relations Gesellschaft (2003). Satzung der DPRG [Charter of the DPRG]. Retrieved on April 2, 2018 from http://www.dprg.de/pdf/DPRGSatzung.pdf

Ebrahim, A. (2003). Accountability in practice: Mechanisms for NGOs. World Development 31(4), 813-829. doi: 10.1016/S0305-750X(03)00014-7

Friedman, T. L. (2005). The world is flat: A brief history of the twenty-first century. New York, NY: Farrar, Straus and Giroux.

Friday, R. A. (1989). Contrasts in discussion behaviors of German and American managers. International Journal of Intercultural Relations, 13(4). doi: 10.1016/01471767(89)90022-9

Froehlich, R., \& Peters, S. B. (2015). Non-profit-PR. In R. Froehlich, S. Peters, \& G. Bentele (Eds.), Handbuch der Public Relations [Public relations handbook]. Wiesbaden, Germany: Springer VS

Geertz, C. (1973). The interpretations of cultures. New York, NY: Basic Books.

Ginesta, X., Ordeix, E., \& Rom, J. (2017). Managing content in cross-cultural public relations campaigns: A case study of the Paris terror attack. American Behavioral Scientist, 61(6), 624-632. doi: $10.1177 / 0002764217693280$

Gregory, A. (2000). Planning and managing public relations campaigns (2nd ed.) London, GB: Kogan Page.

Gregory, A. (2003). Public relations in practice (2nd ed.). Sterling, VA: Kogan Page.

Grice, H. P. (1975). Logic and conversation. In P. Cole \& J. L. Morgan (Eds.), Syntax and semantics: Vol 3. Speech acts (pp. 41-58). New York, NY: Academic Press. 
Grunig, L. A. \& Grunig, J. E. (2003). Public relations in the United States: A generation of maturation. In K. Sriramesh \& D. Vercic (Eds.), The global public relations handbook: Theory, research and practice (2nd ed.) (pp. 323-355). New York: Routledge.

Grunig, L. A. \& Grunig, J. E. (2009). Public relations in the United States: A generation of maturation. In K. Sriramesh \& D. Vercic, (Eds.). The global public relations handbook: Theory, research and practice (pp. 323-255). New York: Routledge.

Grunig, J., \& Hunt, T. (1984). Managing public relations. New York: Holt, Rinehart and Winston

Gudykunst, W. B. (2005). Theorizing about intercultural communication. Thousand Oaks, CA: Sage.

Gudykunst, W. B., \& Kim, Y. Y. (2003). Communicating with strangers: An approach to intercultural communication (4th ed.). Boston, MA: McGraw-Hill.

Gudykunst, W. B., \& Nishida, T. (1989). Theoretical perspectives for studying intercultural communication. In M. K. Asante \& W.B. Gudykunst (Eds.), Handbook of international and intercultural communication (pp. 17-46). Newbury Park, CA: Sage.

Gudykunst, W. B., Yoon, Y., Nishida, T. (1987). The influence of individualism- collectivism on perceptions of communication in ingroup and outgroup relationships. Communication Monographs, 54(3), 295-306. doi: 10.1080/03637758709390234

Hall, E. T. (1959). The silent language. Garden City, NY: Doubleday \& Company.

Hall, E. T. (1976). Beyond culture. Garden City, NY: Anchor Press.

Hall, E., \& Hall, M. (1990). Understanding cultural differences: Germans, French and Americans. Yarmouth, ME: Intercultural Press. 
Hammer, M. R. (1998). A measure of intercultural sensitivity: The intercultural development inventory. In S. M. Fowler \& M. G. Mumford (Eds.), Intercultural sourcebook: Crosscultural training methods (2nd Ed.) (pp. 61-72). Yarmouth, ME: Intercultural Press.

Held, D. \& McGrew, A. (2000). The global transformations reader: An introduction to the globalization debate. Cambridge, UK: Polity Press.

Hendrix, J. A. (1998). Public relations cases (4th ed.). Belmont, CA: Wadsworth.

Hinner, M. B. (2004). Comparing and contrasting German and American business cultures. In L.A. Samovar, R.E. Porter, E.R. McDaniel, \& C. S. Roy (Eds.), Communication between cultures (pp. 273-287). Boston, MA: Cengage Learning

Hodges, C. (2006). PRP culture: A framework for exploring public relations practitioners as cultural intermediaries. Journal of Communication Management, 10(1), 80-93. doi: $10.1108 / 13632540610646391$

Hofstede, G. (1980). Culture's consequences. Beverly Hills, CA: Sage.

Hofstede, G. (1984). Culture's consequences: International differences in work-related values. London: Sage.

Hofstede, G. (2001). Culture's consequence: Comparing values, behaviors, institutions, and organizations across nations (2nd ed.). Thousand Oaks, CA: Sage.

Hofstede Insights (2018). National culture. Retrieved on January 6, 2016 from https://www.hofstede-insights.com/models/national-culture/

Hon, L. C., \& Brunner, B. (2000). Diversity issues and public relations. Journal of Public Relations Research, 12(4), 309-340. doi: 10.1207/s1532754xjprr1204_2 
Huang, Y. C. (2012). Culture and Chinese public relations research. In K. Sriramesh, \& D. Vercic (Eds.), Public relations: Links and implications (pp. 91-104). New York, NY: Routledge.

Huck, S. (2004). Public relations ohne Grenzen? Eine explorative Analyse der Beziehung zwischen Kultur und Oeffentlichkeitsarbeit von Unternehmen [Limitless public relations? An explorative analysis of the relationship between culture and companies' public relations]. Wiesbaden, Germany: Springer VS.

Jain, R. De Moya, M., \& Molleda, J. (2014). State of international public relations research: Narrowing the knowledge gap about the practice across borders. Public Relations Review, 40(3), 595-597. doi: 10.1016/j.pubrev.2014.02.009

Jiang, J., \& Wei, R. (2013). Power distance and online organization-public relationship building: a comparative analysis of US and Chinese corporate websites, Chinese Journal of Communication, 6(1), 81-102. doi: 10.1080/17544750.2013.753501

Kim, Y. Y. (1988). Communication and cross-cultural adaptation: An integrative theory. Philadelphia, PA: Multilingual Matters.

Kim, Y. Y. (2001). Becoming intercultural: An integrative theory of communication and crosscultural adaptation. Thousand Oaks, CA: Sage.

Kim., S., \& Reber, B. H. (2008). Public relations’ place in corporate social responsibility: Practitioners define their role. Public Relations Review, 34, 337-342. doi: 10.1016/j.pubrev.2008.07.003

Landis, D., Bennett, J. M., \& Bennett, M. J. (2004). Handbook of intercultural training (3rd ed.) Thousand Oaks, CA: Sage. 
Lee, S. (2004) A theoretical model of national image processing and international public relations._Mass Communications - Dissertations. 26. Retrieved from https://surface.syr.edu/com_etd/26

L'Etang, J. (2012). Thinking about public relations and culture: Anthropological insights and ethnographic futures. In K. Sriramesh \& D. Vercic (Eds.), Public relations: Links and implications (pp. 218-235). New York, NY: Routledge.

Lewis, R. (2006). When cultures collide: Leading across cultures (3rd ed.) Boston, MA: Nicholas Brealey.

Lincoln, Y. S., \& Guba, E. G. (1985). Naturalistic Inquiry. Beverly Hills, CA: Sage.

Lindlof, T. R., \& Taylor, B. C. (2011). Qualitative communication research methods. Thousand Oaks, CA: Sage.

Lu, L. (2012). Etic or emic? Measuring culture in international business research. International Business Research, 5(5), 109 - 115 doi: 10.5539/ibr.v5n5p109

Martell, L. (2007). The third wave in globalization theory. International Studies Review, 9(2), 173-196. doi: 10.1111/j.1468-2468.2007.00670.x

Marston, J. E. (1963). The nature of public relations. New York, NY: McGraw-Hill.

McCracken, G. (1988). The long interview. Newbury Park, CA: Sage.

McKie, D., \& Munshi, D. (2007). Reconfiguring public relations: Ecology, equity, and enterprise. New York, NY: Routledge.

McSweeney, B. (2002). Hofstede's model of national cultural differences and their consequences: A triumph of faith - A failure of analysis. Human Relations, 55(1), 89118. doi: $10.1177 / 0018726702551004$ 
Miller, D., \& Dinan, W. (2003). Global public relations and global capitalism. In D. Demers (Ed.), Terrorism, globalization and mass communication (pp. 193-214). Spokane, WA: Marquette Books.

Moosmueller, A., \& Schoenhuth, M. (2009). Intercultural competence in German discourse. In D. K. Deardorff (Ed.), The SAGE Handbook of intercultural competence (pp. 209-232). Thousand Oaks, CA: Sage.

Morris, M. W., Leung, K., Ames, D., \& Lickel, B. (1999). Views from inside and outside: Integrating emic and etic insights about culture and justice judgment. Academy of Management Review, 24, 761-796. doi: 10.5465/amr.1999.2553253

Mushtasha, A., \& De Troyer, O. (2009). Cross-culture and website design: Cultural movements and settled cultural variables. In N. Aykin (Ed.), Internationalization, design and global development (pp. 69-78). Berlin, Germany: Springer.

Najam, A. (1996). NGO accountability: A conceptual framework. Development Policy Review, 14(4), 339-354. doi: 10.1111/j.1467-7679.1996.tb00112.x

Ngai, P. B. (2000). Nonverbal communicative behavior in intercultural negotiations: Insights and applications based on findings from Ethiopia, Tanzania, Hong Kong, and the China mainland. World Communication, 29(4), 5-35.

Oetzel, J., Ting-Toomey, S., Chew-Sanchez, M. I., Harris, R., Wilcox, R., \& Stumpf, S. (2003). Face and facework in conflicts with parents and siblings: A cross-cultural comparison of Germans, Japanese, Mexicans, and U.S. Americans. The Journal of Family Communication, 3(2), 67-93. doi: 10.1207/S15327698JFC0302

Olasky, M. N. (2013). Corporate public relations: A new historical perspective. New York, NY: Routledge. 
Oliveira, M. (2013). Multicultural environments and their challenges to crisis communication. Journal of Business Communication, 50, 253-277. doi: 10.1177/0021943613487070

Parekh, B. (2000). Rethinking multiculturalism: Cultural diversity and political theory. Cambridge, MA: Harvard University Press.

Parkinson, \& Ekachai. (2006). International and intercultural public relations: A campaign case approach. Boston, MA: Allyn \& Bacon.

Pike, R. 1966. Language in relation to a unified theory of the structure of human behavior. The Hague, Netherlands: Mouton.

Public Relations Association of America. (2018a). PRSA Code of ethics: Preamble. Retrieved on December 27, 2018 from https://www.prsa.org/ethics/code-of-ethics/

Public Relations Association of America. (2018b). About public relations. Retrieved on February 23, 2018 from https://www.prsa.org/all-about-pr/

Rebeil Correra, M. A., \& Herrera B., M. V. (2012). Public relations in Mexico: Culture and challenges vis-à-vis globalization. In K. Sriramesh \& D. Vercic, Public relations: Links and implications (pp. 243-257). New York, NY: Routledge.

Rhee, Y. (2002). Global public relations: A cross-cultural study of the excellence theory in South Korea. Journal of Public Relations Research, 14(3), 159 - 184. doi: 10.1207/s1532754xjprr1403_1

Roach, K. D., \& Byrne, P. R. (2001). A cross- cultural comparison of instructor communication in American and German classrooms. Communication Education, 50(1), 1-14. doi: $10.1080 / 03634520109379228$

Roth, J., \& Koeck, C. (2004). Culture communication skills. Munechen, Germany: Bayerischer Volkshochschulverband. 
Sandelowski, M. (1995). Sample size in qualitative research. Research in Nursing \& Health, 18(2), 179 - 183. doi: 10.1002/nur.4770180211

Schultz, M., Hatch, M. J., \& Holten Larsen, M. (2000). The expressive organizations: Linking identity, reputation, and the corporate brand. New York, NY: Oxford University Press.

Seitel, F. P. (2007). The practice of public relations (10th ed.). Upper Saddle River, NJ: Pearson.

Sennett, R. (2006). The culture of the new capitalism. New Haven, CT: Yale University Press.

Sheehan, M., \& Xavier, R. (2009). Public relations campaigns. South Melbourne, Australia: Oxford University Press.

Shome, R. (2012). Mapping the limits of multiculturalism in the context of globalization. International Journal of Communication 6, 144-165.

Sison, M. D. (2009). Whose cultural values? Exploring public relations' approaches to understanding audiences. Prism 6(2). Retrieved from http://praxis.massey.ac.nz/prism_on-line_journ.htm

Sison, M. D. (2017). Communication across, within, and between cultures: Toward inclusion and social change. Public Relations Review 43, 130-132. doi: 10.1016/j.pubrev.2016.10.015

Spitzberg, B. H. (2000). What is good communication? Journal of the Association for Communication Administration, 29, 103-119.

Spitzberg, B. H. (2007). CSRS: The conversational skills rating scale: An instructional assessment of interpersonal competence (NCA Diagnostic Series, 2nd ed.). Annandale, VA: National Communication Association.

Spitzberg, B. H. (2015) A model of intercultural communication competence. In L.A. Samovar, R.E. Porter, E.R. McDaniel, \& C. S. Roy (Eds.), Intercultural communication: A reader (14th ed.) (pp. 343-354). Boston, MA: Cengage Learning. 
Spitzberg, B. H., \& Changon, G. (2009). Conceptualizing intercultural competence. In D. K. Deardorff (Ed.) The SAGE handbook of intercultural competence (pp. 2-52). Thousand Oaks, CA: Sage.

Spradley, J. P. (1979). The ethnographic interview. New York, NY: Holt, Rinehart and Winston.

Sriramesh, K. (2002). The dire need for multiculturalism in public relations education: An Asian perspective. Journal of Communication Management 7(1), 54-70. doi:

$10.1108 / 13632540310807250$

Sriramesh, K. (2004). Epilogue: The need for multiculturalism in public relations education in Asia. In K. Sriramesh (Ed.), Public relations in Asia: An anthology (pp. 321-341). Singapore: Thomson Learning.

Sriramesh, K. (2009). Globalisation and public relations: The past, present, and the future. PRism 6(2). Retrieved from http://praxis.massey.ac.nz/prism_on-line_journ.html

Sriramesh, K. (2012). Culture and public relations: Formulation the relationship and its relevance to the practice. In K. Sriramesh, \& D. Vercic (Eds.), Public relations: Links and implications (pp. 9-24).New York, NY: Routledge.

Sriramesh, K., Grunig, J. E., \& Dozier, D. M. (1996). Observation and measurement of two dimensions of organizational culture and their relationship to public relations. Journal of Public Relations Research, 8, 229-261. doi: 10.1207/s1532754xjprr0804_02

Sriramesh, K., Kim, Y., \& Takasaki, M. (1999). Public relations in three Asian cultures: An analysis. Journal of Public Relations Research, 11, 271-292. doi:

10.1207/s1532754xjprr1104_01

Sriramesh, K., \& Vercic, D. (Eds.). (2009). The global public relations handbook: Theory, research and practice (2nd ed.). New York: Routledge. 
Sriramesh, K., \& Vercic, D. (2012). (Eds.), Public relations: Links and implications. New York, NY: Routledge.

Sriramesh, K., \& White, J. (1992). Societal culture and public relations. In J.E. Grunig (Ed.), Excellence in public relations and communication management (pp. 597-614). Hillsdale, NJ: Lawrence Erlbaum Associates.

Statistisches Bundesamt (Destatis). (2018). Migration \& integration. Retrieved on December 6, 2017 from

https://www.destatis.de/EN/FactsFigures/SocietyState/Population/MigrationIntegration/ MigrationIntegration.html.

Strauss, A., \& Corbin, J. (1998). Basics of qualitative research: Grounded theory procedures and techniques (2nd ed.). Thousand Oaks, CA: Sage.

Taylor, M. (2000). Cultural variance as a challenge to global public relations: A case study of the Coca-Cola scare in Europe. Public Relations Review, 26, 277-293. doi: 10.1016/S03638111(00)00048-5

Taylor, M., \& Kent, M.L. (1999). Challenging assumptions in international public relations: When government is the most important public. Public Relations Review, 25, 131-144. doi:10.1016/S0363-8111(99)80158-1

Ting-Toomey, S. (2012). Communication across cultures. New York, NY: The Guilford Press. Ting-Toomey, S., \& Kurogi, A. (1998). Facework competence in intercultural conflict: An updated face-negotiation theory. International Journal of Intercultural Relations, 22, 187-225. doi: 10.1016/s0147-1767(98)00004-2 
U.S. Bureau of Labor Statistics. (2017). Occupational outlook handbook: Public relations specialists. Retrieved from https://www.bls.gov/ooh/media-andcommunication/mobile/public-relations-specialists.htm

U.S. Census Bureau. (2016). Characteristics of the U.S. population by generational status: 2013. Washington, D.C. Retrieved from https://www.census.gov/content/dam/Census/library/publications/2016/demo/P23214.pdf

Vercic, D. (2011). Public relations firms and their three occupational cultures. In K. Sriramesh, \& D. Vercic (Eds.), Public relations: Links and implications (pp. 243-257). New York, NY: Routledge.

Vercic, D., van Ruler, B., Buetschie, G., Flodin, B. (2001). On the definition of public relations: A European view. Public Relations Review 27, 373-387. doi: 10.1016/s03638111(01)00095-9

Victor, D. (April 5, 2017). Pepsi pulls ad accused of trivializing Black lives matter. The New York Times. Retrieved from https://www.nytimes.com/2017/04/05/business/kendalljenner-pepsi-ad.html

Yeo, S. L., \& Pang, A. (2017). Asian multiculturalism in communication: Impact of culture in the practice of public relations in Singapore. Public Relations Review, 43, 112-122. doi:10.1016/j.pubrev.2016.10.014 


\section{APPENDIX A: INFORMED CONSENT}

\section{Dear participants:}

I am a graduate student under the direction of Professor John Baldwin in the School of Communication at Illinois State University. As part of a course requirement I am conducting research to better understand how intercultural differences in the United States and Germany have an impact on PR Practitioners and their development of campaigns.

I invite you to participate. Your participation-will involve an open-ended interview about your development as a PR practitioner, including education and skills, as well as your perception of cultural values and their impact on the development and adjustment of PR campaigns. The interview will be conducted via audio technology (Skype, Facetime, or phone) and will be audiorecorded, with your permission, to ensure accuracy of recording your words. Recordings will be erased after transcription and will not have anything that links your identity to the digital files. The interview may take 30 minutes to one hour. To participate, you must be at least 18 years of age and work as a PR practitioner.

Your participation in this study is voluntary. You may refuse to answer any question. You may skip or refuse to answer questions if you feel uncomfortable, and if you choose not to participate or to withdraw from the study at any time, there will be no penalty. Your responses are confidential - any information that might allow someone to identify you will not be disclosed. Your responses will be joined with those of other participants to develop themes for research presentation at conference or in publication.

As a participant, you may experience minor discomfort when talking about personal experiences. You may be concerned about confidentiality or that there will be social repercussions or loss of job if you talk about your company; however, nothing that identifies you or your company will appear in any write-up or presentation of the research findings. beyond this there are no risks involved with participation beyond those of everyday life. Although there may be no direct benefit to you, a possible benefit of your participation is for PR and intercultural communication researchers and practitioners who want to gain more knowledge in this field and learn about possible ways to raise awareness and work effectively in our globalized world.

Please direct any questions and/or comments to Dr. John Baldwin (j******@ilstu.edu). If you have any questions about your rights as a subject/participant in this research, or if you feel you have been placed at risk, you can contact the Research Ethics \& Compliance Office at Illinois State University at (309) 438-2529. This project has been reviewed and approved by the Illinois State University Institutional Review Board.

Sincerely, Leila Schmidt, Graduate Student, School of Communication Illinois State University 1******@ilstu.edu 


\section{APPENDIX B: INTERVIEW PROTOCOL}

Demographic Questions

Please tell me your name, age, country where you are from and where you are working (city)

- Education level / job

- Ethnicity

- Gender

- Type of job (type of company - cooperate/NGO/Agency)

Interview Questions for PR Practitioners:

- How were you trained/educated to work in the PR field? Through studies? Practical experiences? Trainee Programs?

- Tell me about your development as a PR Practitioner - from the beginning until now!

- What skills do you consider to be necessary in order to work effectively and efficiently in the PR field?

- What does Public Relations mean to you? How would you define it?

- What do you have to be aware of whenever you develop specific campaigns?

- What role do the audience or other stakeholders play in the development of PR campaigns?

- What strategies do you use to achieve specific PR goals? For example: Attending events where specific age groups will be present, using specific social media platforms, contacting the media, ...)?

- How aware are you of the cultural values of your target audience?

- What role does culture play when developing PR campaigns?

- Have you only developed PR campaigns for a specific group/country? If so, give some examples and talk about the aspects that make them unique for the specific audience.

- Have you developed campaigns that are run in different countries or considered to be "multicultural or global campaigns"?

If so, how do they differ from national ones?

- If so, how was a campaign adjusted to other audiences/ countries?

- Please provide an example for a campaign that you recently (within the past year) developed - Talk about what made it unique, what you paid attention to, what role culture and the target audience played, what challenges and restrictions/limitations you experienced.

○ What was easy and difficult about it?

- What was the outcome/critique/praise?

D Did it fulfill its purpose? If yes, how? If no, why not?

- How has the development of campaigns changed over the past few years for the companies that you've been working for? What did you notice? If possible, provide some examples!

- What role does globalization play for the development of campaigns? Is it easier/more difficult to develop campaigns because of a more international audience even without one country/culture?

- Have you been taught the importance of culture? Have you been trained to adjust yourself/your work to it? 
- Please provide an example for a campaign that went wrong because of a lack of cultural awareness/ unintentional exclusions / no addressing of values?

- What made you aware of it? E.g. complaints from the audience or stakeholders?

- What strategies/tactics do you use to measure the outcome of campaigns?

- How do you adjust them to language, social norms, and values?

- Is there anything else that you would like to say about culture and public relations that I have not asked you? 